23

\title{
Переключаемые зеркала-стекла на гидридах металлов
} (обзор)

\author{
(C) В.А. Майоров \\ Новгородский государственный университет имени Ярослава Мудрого, \\ 173003 Великий Новгород, Россия \\ e-mail: Vitaly.Mayorov@novsu.ru
}

Поступила в редакцию 22.01.2019 г.

В окончательной редакции 22.01.2019 г.

Принята к публикации 09.09.2019 г.

В конце XX века было открыто явление изменения оптических свойств от зеркального металлического до прозрачного при гидрировании тонких пленок некоторых хромогенных материалов. Такие устройства получили название „переключаемое зеркало-стекло“. Удивительные свойства новых материалов и возможность создания на их основе умных окон обусловили взрывной рост числа их исследований. Однако недостаточное светопропускание в прозрачном состоянии и ускоренная деградация зеркал при циклических переключениях быстро погасили к ним интерес и резко сократили интенсивность их разработки. Настойчивые двадцатилетние исследования по улучшению оптических свойств и долговечности газо- и электрохромных переключаемых зеркал-стекол позволили довести эти устройства до уровня, близкого к практическому применению. Приведены анализ и обобщение результатов выполненных разработок газо- и электрохромных переключаемых зеркал-стекол и выполнена оценка перспективы коммерческой реализации умных окон на их основе.

Ключевые слова: переключаемые зеркала-стекла, гидриды металлов.

DOI: $10.21883 /$ OS.2020.01.48853.25-19

\section{Введение}

Темпы развития индустрии светопрозрачных конструкций в настоящее время можно сравнить с темпами развития таких современных отраслей деятельности человека, как компьютерная техника, информационные технологии и средства коммуникаций. Причина - желание обеспечить комфортные условия в помещениях и сократить потери энергии через окна, которые составляют $\sim 40 \%$ от общих затрат энергии на содержание зданий. На содержание зданий (отопление, кондиционирование, вентиляция и освещение) затрачивается 30-40\% всей энергии, потребляемой человечеством.

Особый интерес вызывают динамические окна, свойства которых могут изменяться в соответствии с изменением погодных условий. Другие названия этих окон интеллектуальные, переключаемые или умные (smart windows). Подробно история развития исследований, освоения производства и характеристики различных видов коммерческих умных окон изложены в обзорных работах $[1,2]$. В настоящее время на коммерческой основе выпускаются следующие виды умных окон: электрохромные, термохромные, термотропные и ламинированные стекла с двумя видами полимерных пленок. Это пленки с диспергированными в полимере микрокаплями жидких кристаллов (пленки PDLC - polymer dispersed liquid crystals) и пленки с диспергированными в полимере микрокаплями жидкости с взвешенными частицами (пленки SPD - suspended particles devices).
Из всех видов умных окон лучшими свойствами обладают электрохромные, особенно окна с раздельным регулированием пропускания видимого света и ближнего инфракрасного (БИК) излучения [3,4]. Однако они имеют лучшие, но не идеальные свойства. Регулируемое ослабление проходящих через них БИК излучения и видимого света осуществляется в основном за счет их поглощения, но не отражения. Поглощаемые БИК излучение и видимый свет преобразуются в теплоту, что вызывает повышение температуры стекла (в некоторых случаях до весьма высоких значений $\left.\sim 60^{\circ} \mathrm{C}\right)$. Часть этой теплоты передается внутрь помещения тепловым излучением и конвекцией. Поэтому для этой цели более эффективны устройства, регулирующие пропускание излучения за счет его отражения - переключаемые зеркала-стекла.

\section{История вопроса}

В конце XX века голландские ученые открыли новые хромогенные материалы, тонкие пленки которых могут изменять состояние между зеркальным металлическим и прозрачным полупроводниковым. Такие устройства получили название „переключаемое зеркалостекло“ (switchable mirror). Удивительные свойства новых материалов и возможность создания на их основе умных окон и других разнообразных устройств обусловили взрывной рост числа исследования их свойств и количества публикаций с описанием результатов. В хо- 
де последующего развития событий наблюдаются два отчетливо выраженных периода. В первое десятилетие с 1996 по 2006 г. в ходе интенсивных исследований этого явления в нескольких странах были выявлены недостаточное светопропускание зеркал-стекол в прозрачном состоянии и их быстрая деградация в ходе циклических переключений. Практическое воплощение таких устройств в умных окнах представлялось туманным. Интерес к этим устройствам быстро ослаб, и исследования были свернуты во всех странах, кроме Японии.

Второй десятилетний период продолжается с 2007 г. В это время только одна группа японских исследователей настойчиво продолжает разработку переключаемых зеркал-стекол с целью доводки их до практической реализации в виде коммерческих умных окон.

Результаты выполненных исследований переключаемых зеркал-стекол и перспективы коммерческой реализации умных окон на их основе излагаются в настоящей работе.

\section{Итоги первого десятилетия разработок}

В 1996 г. группа голландских исследователей открыла явление изменения оптических свойств тонких пленок редкоземельных металлов иттрия и лантана при фазовом переходе металл-изолятор [5]. Дигидриды этих металлов $\left(\mathrm{YH}_{2}, \mathrm{LaH}_{2}\right)$ обладают металлическими зеркальными свойствами, тогда как тригидриды $\left(\mathrm{YH}_{3}, \mathrm{LaH}_{3}\right)$ являются полупроводниками и прозрачны в видимой части оптического спектра (рис. 1). Переход из зеркального состояния в прозрачное является обратимым и реализуется при комнатной температуре за счет изменения давления водорода в окружающей газообразной среде. Для иттрия такой переход происходит при составе вблизи $\mathrm{YH}_{2.86}$ (рис. 2). В прозрачном состоянии эти материалы имеют характерный цвет: $\mathrm{YH}_{3}$ - желтоватый, $\mathrm{LaH}_{3}$ - красный. Было обнаружено, что такими свойствами обладают практически все трехвалентные редкоземельные металлы.

Необходимым условием таких превращений является наличие тонкой пленки покрытия из палладия. Палладий выполняет две функции: защищает слой химически активного материала от кислорода и катализирует диссоциативную адсорбцию и ассоциативную десорбцию молекул водорода:

$$
\mathrm{H}_{2} \leftrightarrow 2 \mathrm{H}
$$

Образующиеся атомы водорода затем диффузией транспортируются внутрь твердого материала. При этом палладий образует гидрид $\mathrm{PdH}_{0.6}$

$$
10 \mathrm{Pd}+6 \mathrm{H} \leftrightarrow 10 \mathrm{PdH}_{0.6},
$$

который способствует сквозному транспорту водорода. Важно отметить, что как сам палладий, так и его гидрид являются непрозрачными для света материалами и при толщинах слоя больше 4-5 nm заметно снижают светопропускание через слой.

C учетом предшествующей диссоциации молекул водорода обратимые реакции гидрирования-дегидрирования иттрия описываются уравнением

$$
\mathrm{Y}+2 \mathrm{H} \rightarrow \mathrm{YH}_{2}+\mathrm{H} \leftrightarrow \mathrm{YH}_{3} .
$$

Пленки редкоземельных металлов и палладия нанометровой толщины наносят методом вакуумного плазмотронного напыления.

Такие устройства получили название „переключаемое зеркало-стекло“ (switchable mirror). Им быстро определили различные перспективные области применения, в том числе переключаемые зеркала-стекла для умных окон, активный слой в волоконно-оптических сенсорах водорода, адсорбционный детектор водорода.

На внешней поверхности стекла падающее солнечное излучение частично отражается и частично проходит внутрь стекла. При прохождении через стекло излучение испытывает многократные внутренние отражения и частично поглощается, остаток излучения выходит через внутреннюю поверхность. При этом выполняется соотношение

$$
\tau+\rho+\alpha=1,
$$

где $\tau, \rho, \alpha$ - спектральные коэффициенты пропускания, отражения и поглощения стекла соответственно. Соотношение между величинами $\tau, \rho, \alpha$ существенно изменяется в зависимости от длины волны $\lambda$ падающего излучения.

Энергия солнечного излучения заключена в диапазоне длин волн от 0.3 до $3.5 \mu \mathrm{m}$. Весь диапазон солнечного излучения делят на три части:

- ультрафиолетовое излучение с длиной волны в диапазоне $0.3<\lambda<0.38 \mu \mathrm{m}$, в котором заключено $5 \%$ энергии солнечного излучения;

- видимый свет $0.38<\lambda<0.78 \mu \mathrm{m}$ содержит $40 \%$ солнечной энергии;

- БИК излучение $0.78<\lambda<3.5 \mu \mathrm{m}$ включает 55\% солнечной энергии.

Для характеристики стекол часто используют оптические показатели, усредненные по отдельным диапазонам солнечного излучения - ультрафиолет, видимый свет, ближнее и дальнее инфракрасное излучение. При этом применяют соответствующие нижние индексы. Например, $\tau_{\text {vis }}$ - коэффициент пропускания видимого света, светопропускание, $\tau_{\mathrm{NIR}}-$ коэффициент пропускания БИК излучения.

Открытие нового явления обусловило всплеск интереса к нему и лавинообразный рост число исследований. В течение нескольких лет были обнаружены и исследованы еще два поколения материалов, обладающих свойством переключаемых зеркал.

Второе поколение составляют сплавы редкоземельных металлов с магнием (Mg-RE). С учетом предшествующей диссоциации молекул водорода реакции 

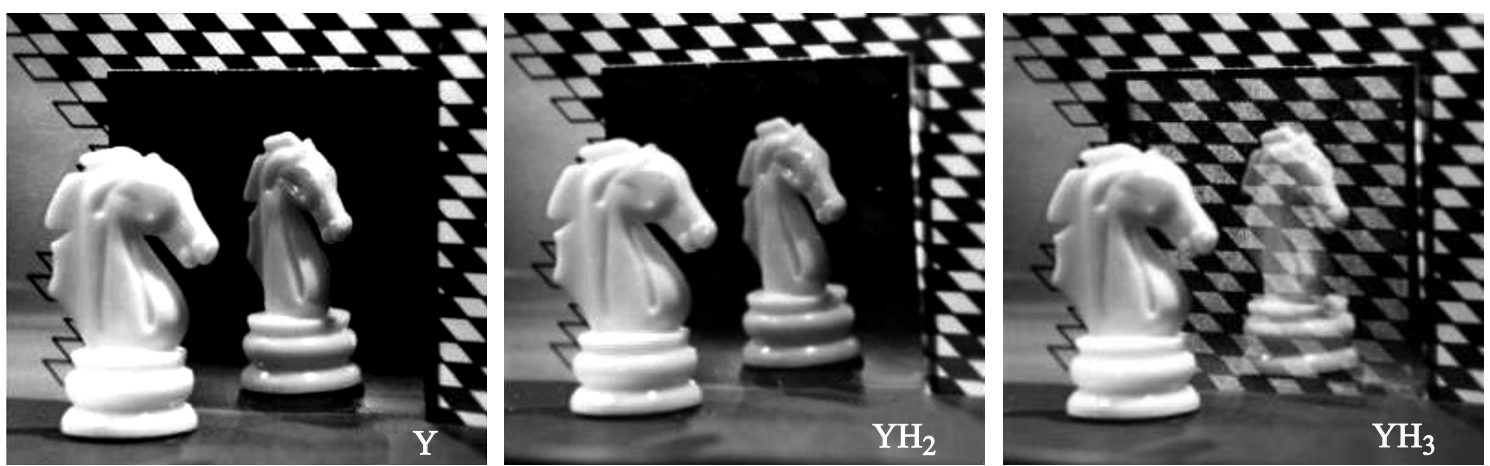

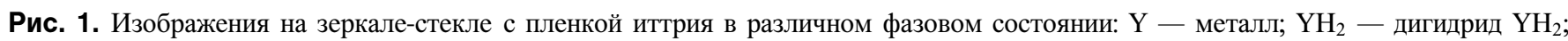
$\mathrm{YH}_{3}$ - тригидрид [5]. Перед зеркалом-стеклом расположена шахматная фигура (конь), за зеркалом-стеклом — шахматная доска.

гидрирования-дегидрирования таких сплавов описываются уравнениями (на примере сплава $\mathrm{Mg}-\mathrm{Y}$ )

$$
\begin{gathered}
\mathrm{Mg}+2 \mathrm{H} \leftrightarrow \mathrm{MgH}_{2}, \\
\mathrm{Y}+2 \mathrm{H} \rightarrow \mathrm{YH}_{2}+\mathrm{H} \leftrightarrow \mathrm{YH}_{3} .
\end{gathered}
$$

На рис. 3 приведены оптические свойства сплава магния с гадолинием - первого из выявленных таких материалов. Видимый свет заключен в диапазоне длин волн от 380 до $780 \mathrm{~nm}$. Тригидрид чистого гадолиния не пропускает левую (голубую) часть видимого спектра, и поэтому имеет красно-желтый цвет. При увеличении содержания магния в сплаве спектральная характеристика перемещается влево-вверх, и пленка гидрида сплава пропускает видимый свет во всем его диапазоне - пленка становится оптически нейтральной и не изменяет цвет пропускаемого света. При этом значительно увеличивается величина коэффициента пропускания. Важно также и то, что магний широко распространен и доступен.

В последующих поколениях переключаемых зеркалстекол в качестве материала активного слоя-пленки используются сплавы магния с переходными (3-е поколение) или щелочноземельными металлами (4-е), а также соединения магния с оксидами переходных металлов титана $\mathrm{TiO}_{2}$ и ниобия $\mathrm{Nb}_{2} \mathrm{O}_{5}$ (5-е). Активный слой во всех вариантах изготавливается вакуумным магнетронным напылением одновременно двух (или более) компонентов при равномерном распределении их атомов по структуре материала. Такие материалы в дальнейшем будем называть сплавами, поскольку сплавы однородные вещества, независимо от вида входящих в них компонентов (металлы, неметаллы, окислы ит.п.), а также независимо от типа образованной системы (твердые растворы, химические соединения, смеси фаз) и от способа их получения.

Третье поколение переключаемых зеркал-стекол составили сплавы магния с доступными переходными металлами $\mathrm{Ni}, \mathrm{Co}, \mathrm{Mn}, \mathrm{Fe}, \mathrm{Ti}[8,9]$. Оптические характеристики всех сплавов зависят от соотношения между содержанием компонентов, и имеется диапазон состава, в котором светопропускание имеет наибольшую величину. При этом материалы третьего поколения обладают более высокими светопропускательными свойствами по сравнению с материалами обоих предыдущих поколений.

Лучшими оптическими свойствами среди материалов третьего поколения обладают сплавы $\mathrm{MgNi}_{x}$ при $0.1<x<0.33\left(\mathrm{Mg}_{10} \mathrm{Ni}-\mathrm{Mg}_{3} \mathrm{Ni}\right)[10]$.

С учетом предшествующей диссоциации молекул водорода реакции гидрирования-дегидрирования сплавов $\mathrm{Mg}-\mathrm{Ni}$ описываются уравнениями

$$
\begin{gathered}
\mathrm{Mg}+2 \mathrm{H} \leftrightarrow \mathrm{MgH}_{2}, \\
\mathrm{Mg}_{2} \mathrm{Ni}+4 \mathrm{H} \leftrightarrow \mathrm{Mg}_{2} \mathrm{NiH}_{4} .
\end{gathered}
$$

При гидрировании сплава $\mathrm{MgNi}_{x}$ образуется смесь гидридов $\mathrm{MgH}_{2}$ и $\mathrm{Mg}_{2} \mathrm{NiH}_{4}$.

На рис. 4 приведены примеры оптических характеристик сплава $\mathrm{MgNi}_{x}$. Светопропускание гидрированной прозрачной пленки $\mathrm{MgNi}_{x}$ зависит от относительного содержания никеля (рис. $4, a$ ). Лучшие результаты достигаются при $0.1<x<0.30\left(\mathrm{Mg}_{10} \mathrm{Ni}-\mathrm{Mg}_{3.3} \mathrm{Ni}\right)$. Нужно отметить, что здесь приведены значения коэффициента пропускания излучения на длине волны $\lambda=670 \mathrm{~nm}$, при которой этот коэффициент имеет максимальное значение.

Спектральные коэффициенты пропускания и отражения пленки состава $\mathrm{Mg}_{5} \mathrm{Ni}$ показаны на рис. $4, b-c$. Здесь для сравнения приведены также и коэффициенты пропускания покрытого пленкой $\mathrm{Pd}$ стекла, пленки $\mathrm{Pd} / \mathrm{Mg}_{2} \mathrm{Ni}$ и в четыре раза увеличенные значения пропускательной способности пленки $\mathrm{Pd} / \mathrm{Mg}$. Толщина всех $\mathrm{Mg}-\mathrm{Ni}$-пленок $40 \mathrm{~nm}$, толщина пленки $\mathrm{Pd}-5 \mathrm{~nm}$.

Коэффициент пропускания пленки гидрида $\mathrm{MgH}_{2}$ в диапазоне видимого света $380-780 \mathrm{~nm}$ очень мал $(\sim 5 \%)$, но остается постоянным, поэтому она имеет темносерый цвет. Коэффициент пропускания пленки гидрида $\mathrm{Mg}_{2} \mathrm{NiH}_{4}$ быстро возрастает по мере увеличения длины волны в диапазоне видимого света. Пленка слабо пропускает левый (голубой) край видимого спектра и имеет красно-коричневый цвет в проходящем свете. 


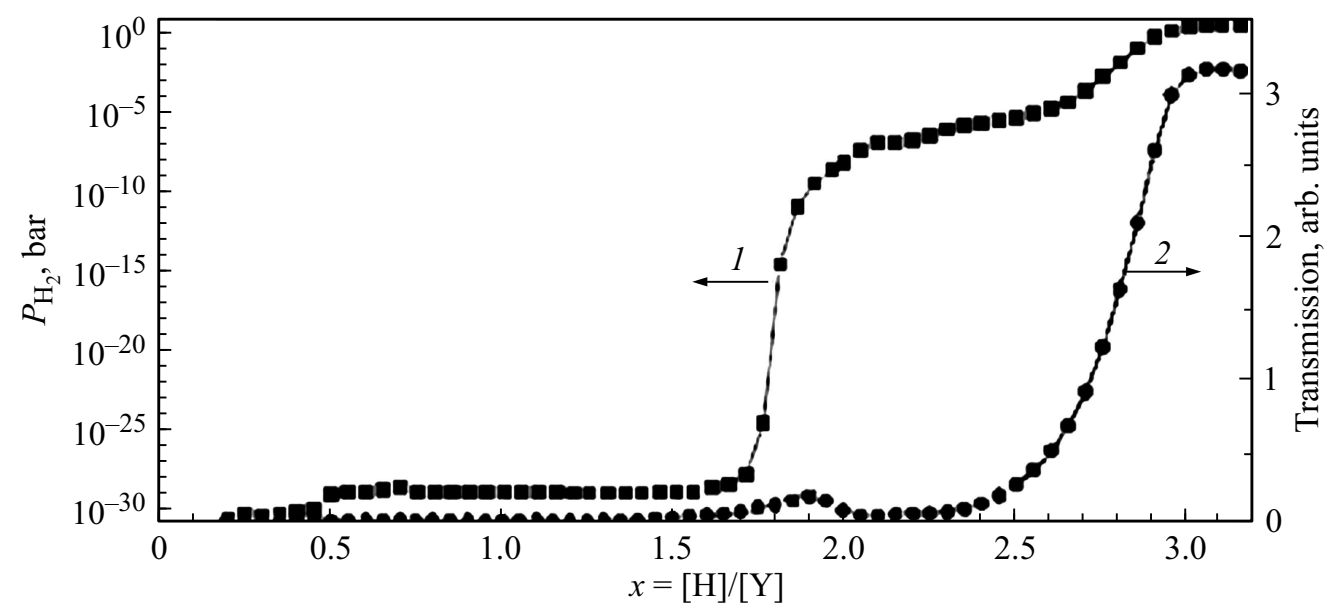

Рис. 2. Изотерма давление водорода-состав $\mathrm{YH}_{x}(1)$ и зависимость пропускания излучения с длиной волны $\lambda=635 \mathrm{~nm}$ от концентрации водорода в соединении $\mathrm{YH}_{x}$-пленки иттрия толщиной $300 \mathrm{~nm}$, покрытой слоем палладия толщиной $15 \mathrm{~nm}(2)$ [6].

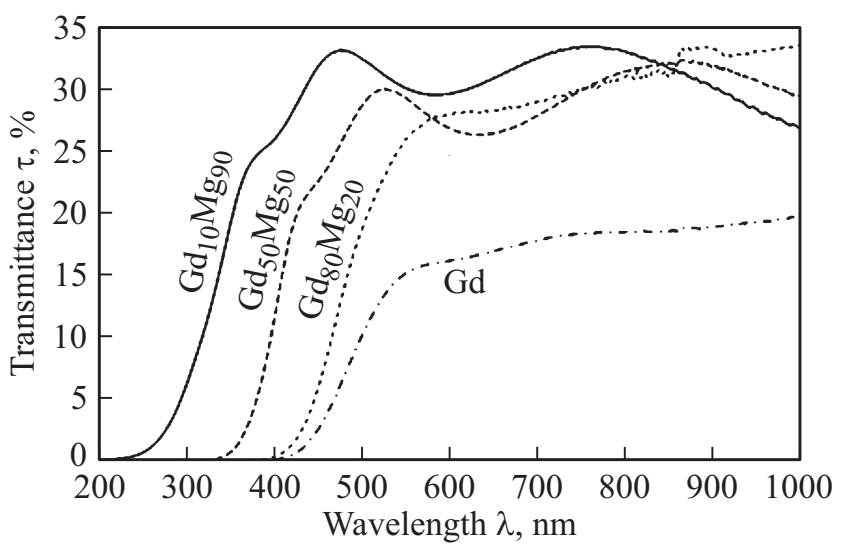

Рис. 3. Спектральные коэффициенты пропускания материалов первого $(\mathrm{Gd})$ и второго $(\mathrm{Mg}-\mathrm{Gd})$ поколений переключаемых зеркал-стекол [7]. Активный слой толщиной $200 \mathrm{~nm}$ покрыт пленкой палладия толщиной $10 \mathrm{~nm}$ и находится в среде водорода при давлении 5 bar.

Пленки гидридов $\mathrm{MgH}_{2}\left(\mathrm{MgNi}_{x}\right.$ при $\left.x=0\right)$ и $\mathrm{Mg}_{2} \mathrm{NiH}_{4}$ $\left(\mathrm{MgNi}_{x}\right.$ при $\left.x=0.50\right)$ имеют невысокие значения коэффициента пропускания: $\tau_{670}=0.05$ и $\tau_{670}=0.20$ соответственно (рис. 4,a). Но смеси этих двух гидридов в диапазоне $0.1<x<0.30$ обладают значительно более высоким светопропусканием. Соотношение между содержанием гидридов $\mathrm{MgH}_{2}$ и $\mathrm{Mg}_{2} \mathrm{NiH}_{4}$ в смеси определяет величину светопропускания и оттенок окраски. Оптимальными свойствами обладает пленка $\mathrm{Mg}_{5} \mathrm{Ni}$ $(x=0.20)$, имеющая бледно желтый цвет.

Пленка $\mathrm{Pd} / \mathrm{Mg}_{2} \mathrm{Ni}$ проявляет резкое изменение оптических свойств при переходе от прозрачного к металлическому состоянию. Коэффициент пропускания видимого света при этом изменяется от 50 до $\sim 1-2 \%$. Это изменение в основном обусловлено изменением отражательной, а не поглощательной способности.
Первые исследования переключаемых зеркал были выполнены с использованием для гидрирования газообразного водорода. В таких опытах при атмосферном давлении периодически меняется состав газообразной среды от чистого воздуха до смеси аргона и $5 \%$ водорода по объему. Но практически одновременно с газофазным способом было обнаружено, что гидрирование переключаемых зеркал можно осуществить также с помощью транспорта ионов водорода (протонов) в электрохимической ячейке из жидкостного [11] или твердофазного электролита [12].

Газофазный метод гидрирования отличается простотой исполнения (рис. 5). Поэтому практически все исследования механизма оптического переключения зеркал-стекол были выполнены с использованием газофазного гидрирования.

Но использование метода газофазного гидрирования переключаемых зеркал в приложении к умным окнам чрезвычайно осложняется практической реализацией газоснабжения таких устройств. На начальной стадии исследований до вопросов практической реализации умных окон на основе переключаемых зеркал-стекол было весьма далеко - нужно было сначала выяснить механизм этого явления.

В течение первого десятилетнего периода с 1996 по 2006 г. были выполнены исследования коллективами ученых в разных странах и получены многочисленные разнообразные результаты по механизму процессов гидрирования-дегидрирования различных материалов.

Здесь отметим основные. Была установлена кинетика процессов гидрирования и дегидрирования в различных материалах. Она зависит от вида и состава сплавов. В магний-никелевых сплавах $\mathrm{Mg}_{8} \mathrm{Ni}-\mathrm{Mg}_{4} \mathrm{Ni}$ образование гидридов при гидрировании начинается на поверхности субстрата-стекла и распространяется послойно в направлении слоя палладия. При дегидрировании зарождение новой фазы - металла - начинается на поверхности слоя палладия и далее распространяется 

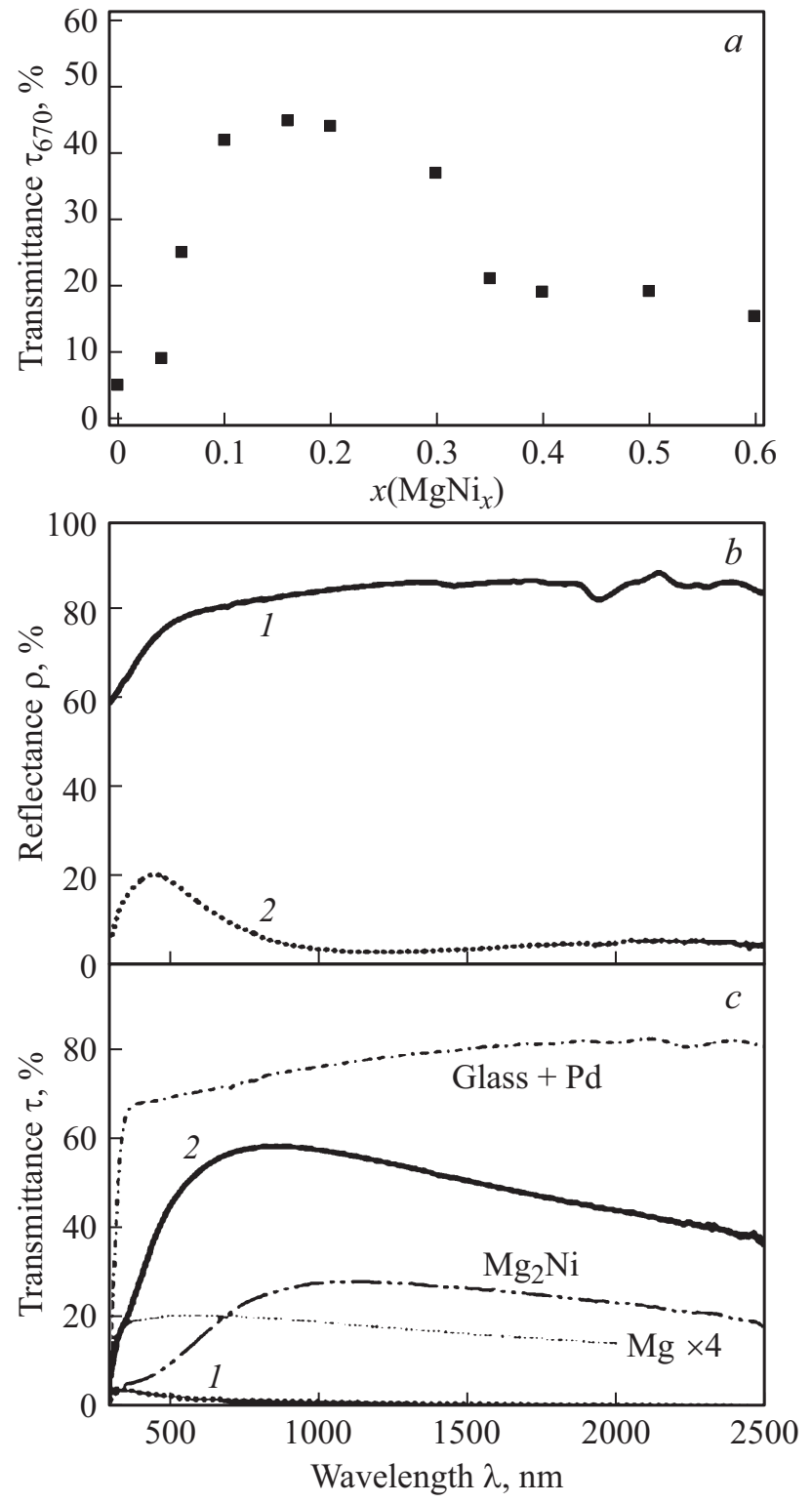

Рис. 4. Оптические характеристики пленки сплавов $\mathrm{MgNi}_{x}$ [10]. Толщина всех $\mathrm{Mg}-\mathrm{Ni}$-пленок $40 \mathrm{~nm}$, толщина $\mathrm{Pd}-$ пленки $5 \mathrm{~nm}$. $a-$ влияние относительной доли $x$ никеля в пленке $\mathrm{MgNi}_{x}$ на коэффициент пропускания $\tau_{670}$ излучения с длиной волны $670 \mathrm{~nm}$ в прозрачном состоянии; $b$ $c$ - спектральные коэффициенты отражения $(b)$ и пропускания $(c)$ пленки $\mathrm{Pd} / \mathrm{Mg}_{5} \mathrm{Ni}$ в металлическом зеркальном (1) и прозрачном гидридном (2) состояниях. Для сравнения на pис. $c$ приведены спектральные коэффициенты пропускания покрытого пленкой Pd стекла (Glass $+\mathrm{Pd}$ ), пленки $\mathrm{Pd} / \mathrm{Mg}_{2} \mathrm{Ni}$ $\left(\mathrm{Mg}_{2} \mathrm{Ni}\right)$ и в четыре раза увеличенные значения коэффициентов пропускания пленки $\mathrm{Pd} / \mathrm{Mg}(\mathrm{Mg} \times 4)$.

послойно в направлении стекла-субстрата [13]. В сплавах магния с редкоземельными металлами образование центров кристаллизации и последующий рост гидридов происходят по всему объему слоя.

Было обнаружено, что при циклических переключениях наблюдается быстрая деградация устройства, за- ключающаяся в увеличении продолжительности смены состояний после переключения и в снижении диапазона изменения светопропускания между состояниями. Основными причинами являются окисление магния [14] и взаимная диффузия палладия и металлов подложки [15]. Довольно быстро для ее устранения было предложено использовать промежуточный защитный слой из оксидов $\mathrm{AlO}_{x}[16]$ или $\mathrm{NbO}_{x}[15]$ между палладием и активным материалом.

В табл. 1 отражена динамика развития исследований газохромных переключаемых зеркал-стекол. Из данных табл. 1 следует, что основные результаты в первое десятилетие получены сотрудниками трех организаций.

Подробно итоги исследований за первый десятилетний период были подведены в обзорной работе [6]. Отмечено, что практическое использования переключаемых зеркал в умных окнах откладывается на неопределенный период вследствие ряда причин:

- слишком мала (< $32 \%)$ светопропускаемость переключаемых зеркал-стекол в прозрачном состоянии;

- быстрая деградация свойств при циклических переключениях вследствие окончательно не установленных причин;

- отсутствуют промежуточные состояния между зеркальным и прозрачным.

При таких неутешительных результатах исследования переключаемых зеркал-стекол были быстро свернуты практически везде.

\section{Второе десятилетие}

В период после 2006 г. только одна группа японских исследователей из National Institute of Advanced Industrial Science and Technology (AIST) настойчиво продолжает разработку переключаемых зеркал-стекол. Цель этих исследований:

- увеличить светопропускание переключаемых зеркал в прозрачном состоянии;

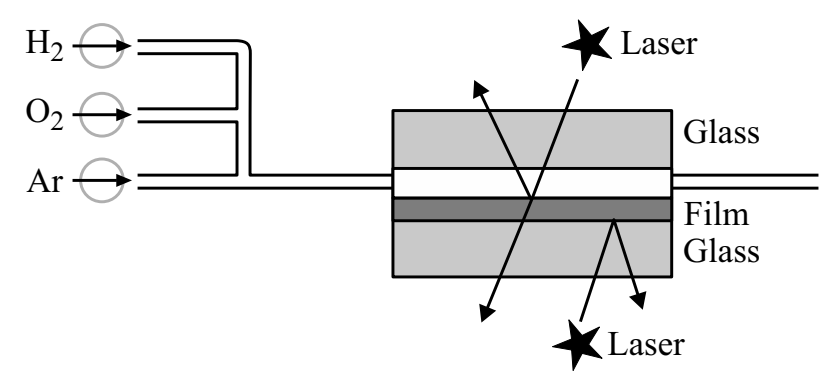

Pис. 5. Экспериментальная установка для исследования кинетики реакции газофазного гидрирования-дегидрирования магний-никелевой пленки [13]. Газовые потоки контролируются вентилями, что позволяет получать газовую смесь заданного состава. Пропускание и отражение от обеих поверхностей пленки лазерного излучения с длиной волны $660 \mathrm{~nm}$ измеряется под углом $10^{\circ}$ к нормали поверхности. 
Таблица 1. Улучшение свойств переключаемых газохромных зеркал-стекол на гидридах металлов по мере применения новых материалов (результаты приведены в хронологическом порядке)

\begin{tabular}{|c|c|c|c|c|c|c|c|c|c|}
\hline Год & Активный слой & $\begin{array}{c}\text { Буферный } \\
\text { слой }\end{array}$ & Катализатор & Покрытие & $\tau_{\mathrm{vis}}, \%$ & $\begin{array}{c}\text { Число } \\
\text { циклов }\end{array}$ & Цвет & $\begin{array}{c}\text { Органи- } \\
\text { зация }\end{array}$ & $\begin{array}{c}\text { Литера- } \\
\text { тура }\end{array}$ \\
\hline 1996 & $\mathbf{Y} ; \mathbf{L a}$ & - & Pd & - & - & - & Желтый & I & [5] \\
\hline 1997 & $\mathbf{M g}-\mathbf{G d} ; \mathbf{M g}-\mathbf{Y}$ & - & $\mathrm{Pd}$ & - & $\sim 28$ & - & Нейтральный & II & {$[7]$} \\
\hline 2000 & $\mathrm{Y}, \mathrm{La}$ & $\mathbf{A l O}_{x}$ & $\mathrm{Pd}$ & - & - & - & Желтый & $\mathrm{I}$ & {$[16]$} \\
\hline 2001 & $\mathrm{Mg}-\mathrm{Ni}$ & - & $\mathrm{Pd}$ & - & 25 & - & Желтый & III & {$[8]$} \\
\hline 2002 & $\mathrm{Mg}-\mathrm{Fe}, \mathrm{Mg}-\mathrm{Mn}, \mathrm{Mg}-\mathrm{Co}$ & - & $\mathrm{Pd}$ & - & $15-20$ & - & - & III & [9] \\
\hline 2003 & Mg-Ti & - & $\mathrm{Pd}$ & - & $\sim 20$ & - & Нейтральный & III & {$[17]$} \\
\hline 2006 & $\mathrm{Mg}-\mathrm{Ni}-\mathrm{Mn}$ & $\mathbf{N b O}_{x}$ & $\mathrm{Pd}$ & - & 32 & 50 & Желтый & III & {$[15]$} \\
\hline 2006 & $\mathrm{Mg}_{4} \mathrm{Ni}$ & $\mathrm{Ti}$ & $\mathrm{Pd}$ & - & 32 & 450 & Желтый & IV & {$[18]$} \\
\hline 2008 & $\mathrm{Mg}_{4} \mathrm{Ni}$ & $\mathrm{Ti}, \mathbf{N b}, \mathbf{V}$ & $\mathrm{Pd}$ & - & $20-30$ & $400-450$ & Желтый & IV & [19] \\
\hline 2008 & $\mathrm{Mg}_{4} \mathrm{Ni}$ & - & $\mathrm{Pd}$ & PTFE & 30 & 1000 & Желтый & IV & {$[20]$} \\
\hline 2009 & $\mathrm{Mg}_{4} \mathrm{Ni}$ & $\mathrm{Ti}$ & $\mathrm{Pd}$ & PTFE & 30 & 1600 & Желтый & IV & [21] \\
\hline 2009 & $\mathrm{Mg}-\mathrm{Ca}$ & - & $\mathrm{Pd}$ & - & 45 & - & Нейтральный & IV & {$[22]$} \\
\hline 2012 & $\mathrm{Mg}-\mathrm{Ba}, \mathrm{Mg}-\mathrm{Sr}$ & - & $\mathrm{Pd}$ & - & $37-45$ & - & Нейтральный & IV & {$[23]$} \\
\hline 2013 & $\mathrm{Mg}-\mathrm{Y}$ & - & $\mathrm{Pd}$ & - & $\sim 30$ & $>10000$ & Нейтральный & IV & [24] \\
\hline 2014 & $\mathrm{Mg}_{4} \mathrm{Y}_{6}$ & Ta & $\mathrm{Pd}$ & - & 44 & $>10000$ & Нейтральный & IV & {$[25]$} \\
\hline 2014 & $\mathrm{Mg}-\mathrm{Zr}-\mathrm{Ni}$ & - & $\mathrm{Pd}$ & - & $30-37$ & - & Желтый & IV & [26] \\
\hline 2015 & $\mathrm{Mg}_{4} \mathrm{Y}_{6}$ & $\mathrm{Ta}$ & $\mathrm{Pd}$ & $\mathrm{TiO}_{2}$ & 68 & - & нейтральный & IV & {$[27]$} \\
\hline 2015 & $\mathrm{Mg}_{4} \mathrm{Ni}$ & - & $\mathbf{P d}{ }_{9} \mathbf{N i}_{1}$ & - & 40 & 175 & Желтый & V & [28] \\
\hline 2017 & $\mathrm{Mg}_{1} \mathrm{Y}_{3}$ & - & $\mathrm{Pd}$ & PTFE & 48 & 1600 & Нейтральный & $\mathrm{V}$ & [29] \\
\hline 2018 & $\mathrm{Mg}_{4} \mathrm{Y}_{6}$ & $\mathrm{Ta}$ & $\begin{array}{c}\mathbf{P} \mathbf{d}_{(1-x)} \mathbf{R u}_{x} \\
0.2 \leq x \leq 0.4\end{array}$ & - & 48 & 15000 & Нейтральный & IV & [30] \\
\hline 2018 & $\begin{array}{c}(1-x) \mathbf{M g}_{-x} \mathbf{T i O}_{2} \\
0.05 \leq x \leq 0.15\end{array}$ & - & $\mathrm{Pd}$ & - & 38 & $>100$ & Нейтральный & China & {$[31]$} \\
\hline 2019 & $\begin{array}{c}(1-x) \mathbf{M} \mathbf{g}_{-x} \overline{\mathbf{N b}}_{2} \mathbf{O}_{5} \\
0.01<x<0.04\end{array}$ & - & $\mathrm{Pd}$ & FC & 46 & $>100$ & Нейтральный & China & {$[32]$} \\
\hline
\end{tabular}

Примечание. 1. Впервые примененные материалы и наиболее значительные результаты выделены жирным шрифтом.

2. I - Vrije Universiteit, Netherlands; II — Philips Research Laboratories, Netherlands; III — Lawrence Berkeley National Laboratory (LBL), USA; IV — National Institute of Advanced Industrial Science and Technology (AIST), Japan; V - Shanghai Institute of Ceramics, China.

3. РТFE - политетрафторэтилен (фторопласт).

4. FC - фторуглерод.

- увеличить ресурс переключений зеркал до числа не менее 10000 , что соответствует одному переключению в день в течение примерно 30 лет;

- довести характеристики переключаемых зеркалстекол как газохромных, так и электрохромных с твердым электролитом до уровня, соответствующего возможности практической реализации в виде коммерческих умных окон.

Результаты разработок группы AIST за истекшее десятилетие опубликованы в большом количестве $(>70)$ статей и $(\sim 10)$ патентов.

В самые последние годы к разработке проблемы подключились китайские специалисты.

\section{Переключаемые газохромные зеркала-зеркала}

Основные достижения сотрудников группы AIST в разработке газохромных переключаемых зеркал-стекол приведены в табл. 1.

\section{Четвертое поколение материалов.}

В ходе исследований было установлено, что способностью менять состояние с металлического зеркального на прозрачное полупроводниковое обладают также сплавы магния с щелочно-земельными металлами, кальцием Са, барием Ва и стронцием $\mathrm{Sr}[22,23]$. Это четвертое поколение таких материалов. Оптические характеристики этих сплавов также зависят от соотношения между содержанием компонентов.

На рис. 6, $a-c$ приведены оптические свойства пленок сплава $\mathrm{Mg}_{(1-x)} \mathrm{Ca}_{x}$. Наиболее высокое светопропускание достигается при молярной доле кальция в сплаве $0.035<x<0.075$ (рис. 6,a).

На рис. 6, $b-c$ изображены спектральные оптические характеристики сплава $\mathrm{Mg}_{0.94} \mathrm{Ca}_{0.06}$. Для сравнения также указаны спектральные пропускательные характеристики двух сплавов третьего поколения $\mathrm{Mg}_{6} \mathrm{Ni}$ и $\mathrm{Mg}_{0.88} \mathrm{Ti}_{0.12}$. Все эти сплавы обладают лучшими светопропускательными свойствами в своей группе. Пропускательная характеристика $\mathrm{Mg}_{0.94} \mathrm{Ca}_{0.06}$ в отмеченном диапазоне 380-780 nm видимого света плоская 

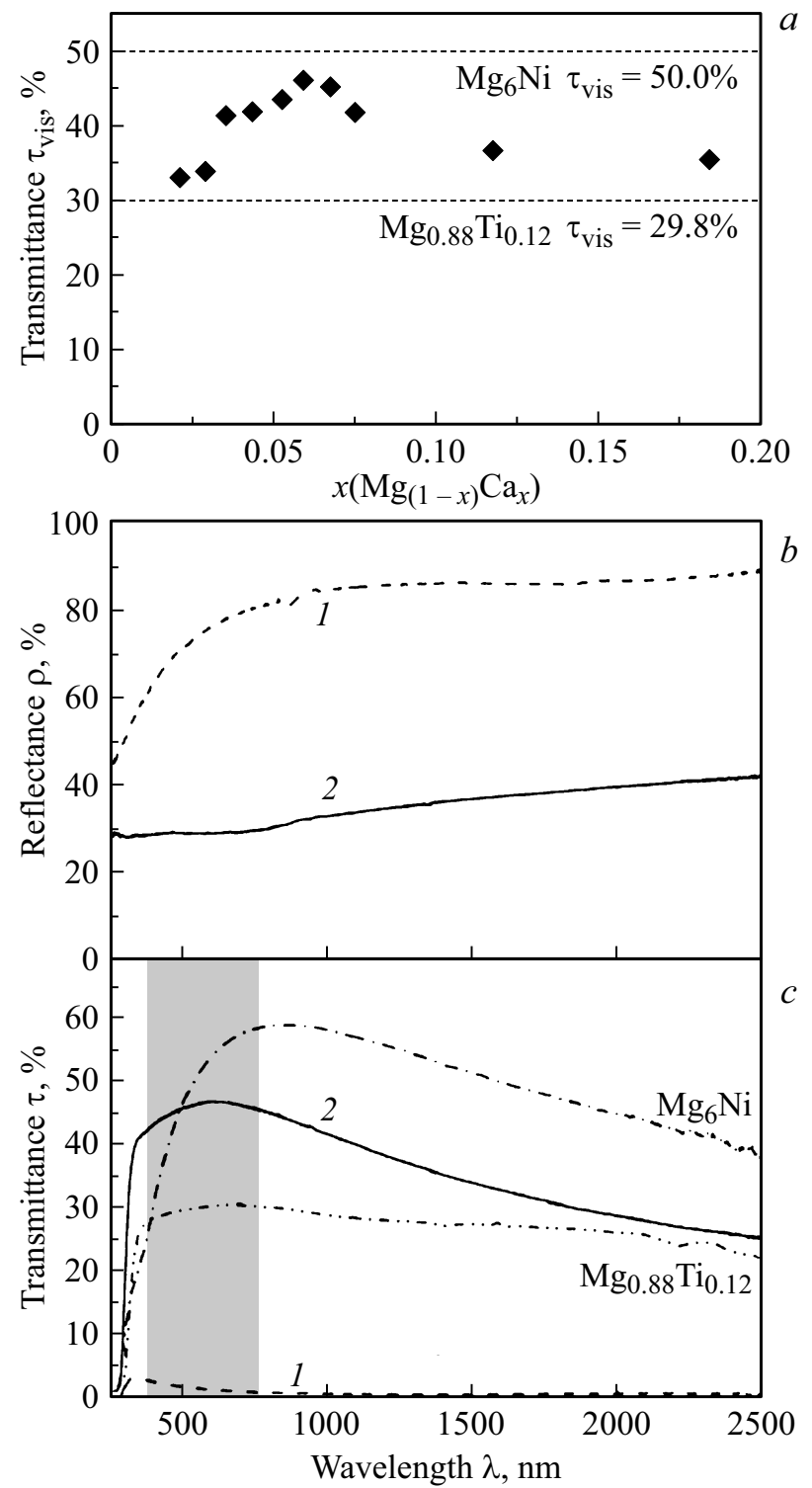

Рис. 6. Оптические характеристики пленки $\mathrm{Mg}_{(1-x)} \mathrm{Ca}_{x}$ [22]. Толщина активного слоя $\mathrm{Mg}-\mathrm{Ca} 60 \mathrm{~nm}$, толщина Pd-пленки $6 \mathrm{~nm}$. $a-$ влияние молярной доли $x$ кальция в сплаве

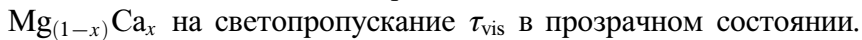
$b-c$ - спектральные коэффициенты отражения $(b)$ и пропускания $(c)$ пленки $\mathrm{Pd} / \mathrm{Mg}_{0.94} \mathrm{Ca}_{0.06}$ в металлическом зеркальном (штриховые линии 1) и гидридном прозрачном (сплошные линии 2) состояниях. На рис. $c$ также приведены для сравнения лучшие пропускательные характеристики в прозрачном состоянии пленок из сплавов третьего поколения $\mathrm{Mg}-\mathrm{Ni}$ и $\mathrm{Mg}-\mathrm{Ti}$.

и имеет величину $\tau_{\text {vis }}=46 \%$. Это значит, что пленка этого материала оптически нейтральна и не искажает пропускаемый свет. Пропускательная характеристики гидрида $\mathrm{Mg}_{6} \mathrm{Ni}$ выше в диапазоне от 500 до $2500 \mathrm{~nm}$, но пропускание света резко снижается на левом, голубом крае видимого спектра. Это значит, что пленка этого материала не является оптически нейтральной и придает блекло-желтый оттенок проходящему сквозь нее свету.
Желтоватый оттенок не желателен для окон, и это является серьезным препятствием для практического применения такого материала в качестве переключаемого зеркала-стекла для умных окон. Пропускательная характеристика гидрида $\mathrm{Mg}_{0.88} \mathrm{Ti}_{0.12}$ также плоская в диапазоне видимого света, но ее значение $\tau_{\text {vis }}=30 \%$ значительно меньше $\tau_{\text {vis }}=46 \%$ - аналогичной характеристики $\mathrm{Mg}_{0.94} \mathrm{Ca}_{0.06}$.

\section{Выявление и устранение причин деградации и повышение долговечности переключаемых зеркал-стекол}

В ходе циклических переключений зеркала-стекла быстро деградируют. На рис. 7 представлен пример таких данных. Длительность цикла составляет $330 \mathrm{~s}$. В течение первых $30 \mathrm{~s}$ при атмосферном давлении подается смесь аргона и 4\% водорода, затем в течение $300 \mathrm{~s}$ - воздух. Переход от металлического состояния к прозрачному происходит очень быстро в течение $3 \mathrm{~s}$. Переход от прозрачного к зеркальному происходит медленнее $(\sim 100 \mathrm{~s})$ вследствие более медленной диффузии водорода сквозь гидрид $\mathrm{MgH}_{2}$. В первых циклах модуляция светопропускания (изменение светопропускания при переключении от прозрачного к зеркальному состоянию) $\Delta \tau_{\mathrm{vis}}=\tau_{\mathrm{vis}}^{+}-\tau_{\mathrm{vis}}^{-}>35 \%$. Но модуляции быстро убывает при циклических переключениях и снижается до $10 \%$ от начального значения после 170 циклов. $\mathrm{C}$ увеличением толщины слоя $\mathrm{Pd}$ скорость снижения модуляции несколько уменьшается, но при этом уменьшается светопропускание. Для слоя $\mathrm{Pd}$ толщиной $1 \mathrm{~nm}$ образец теряет прозрачность после 10-го переключения.

Основные причины деградации:

- диффузия $\mathrm{Mg}$ и $\mathrm{Pd}$ между слоями, что влечет за собой сплавление с палладием, окисление $\mathrm{Mg}$ и образование слоя гидрида $\mathrm{MgH}_{2}$, препятствующего диффузии водорода;

- разрушение слоя $\mathrm{Pd}$ вследствие различного изменения объема $\mathrm{Pd}$ и активного слоя магниевого сплава.

Приведенные в табл. 1 данные наглядно показывают развитие исследований по увеличению циклической стабильности переключаемых зеркал. Циклическая стабильность (неизменность оптических свойств в ходе повторяющихся циклических переключений) является необходимым свойством переключаемых зеркал-стекол, так как определяет максимальный срок их службы. Из расчета одно переключение в сутки при тридцатилетнем сроке эксплуатации оптические свойства не должны ухудшаться более чем на 10\% после 11000 переключений.

Вначале были выполнены исследования по использованию буферного промежуточного металлического слоя. Были использованы металлы Ti, Nb, V. Слой этих металлов толщиной $2 \mathrm{~nm}$ позволил примерно в три раза (от 50 до 450) увеличить число переключений без наступления заметной деградации. Лучшими свойствами из этих трех металлов обладает Тi $[18,19]$. 


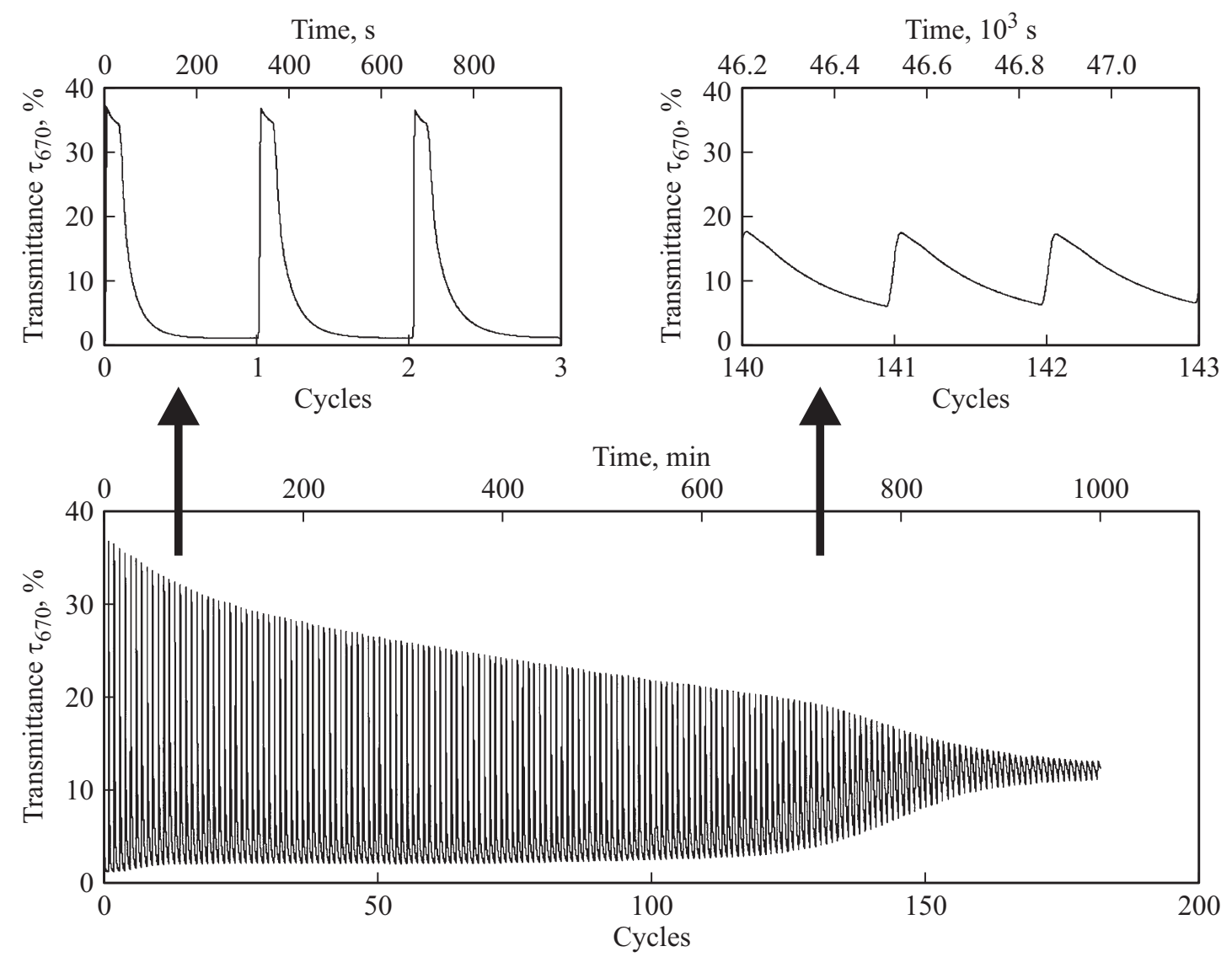

Рис. 7. Изменение коэффициента пропускания излучения с длиной волны $\lambda=670 \mathrm{~nm}$ пленки $\mathrm{Pd} / \mathrm{Mg}_{4} \mathrm{Ni}\left(\mathrm{Pd}-4 \mathrm{~nm}, \mathrm{Mg}_{4} \mathrm{Ni}-\right.$ $40 \mathrm{~nm})$ в ходе циклических переключений [33].

Далее было использовано нанесенное на внешнюю поверхность палладия покрытие из политетрафторэтилена (PTFE), которое предохраняет $\mathrm{Mg}$ от окисления. Слой этого материала толщиной $900 \mathrm{~nm}$ позволил увеличить число циклов до 1000 [20]. Сочетание буферного слоя из Ті толщиной $2 \mathrm{~nm}$ и внешнего слоя толщиной $900 \mathrm{~nm}$ из РТFЕ позволило увеличить число переключений до $\sim 1600$ [21]. Структура переключаемого зеркала описывается формулой стекло/ $\mathrm{Mg}_{4} \mathrm{Ni} / \mathrm{Ti} / \mathrm{Pd} / \mathrm{PTFE}$.

Применение буферного металлического и внешнего фторопластового слоев не защитили слой палладия от разрушения. Тщательные исследования позволили установить, что причиной является деформации пленки $\mathrm{Pd}$ вследствие различного объемного расширения материалов пленки и активного слоя при переключениях [33-35]. Причем образование многочисленных вздутий-кратеров диаметров $\sim 40 \mathrm{~nm}$ в пленке палладия отчетливо наблюдается на полученных с помощью электронного микроскопа фотоснимках.

В табл. 2 приведены данные по относительному изменению объемов $\mathrm{Pd}$ и металлов активного слоя при фазовых переходах гидрирования-дегидрирования.

При фазовых переходах гидрирования-дегидрирования относительное изменение объема катализатора $\mathrm{Pd} \leftrightarrow \mathrm{PdH}_{0.6}$ составляет $10 \%$, а относительное изменение
Таблица 2. Относительное изменение объема при фазовых переходах гидрирования-дегидрирования

\begin{tabular}{c|c|c}
\hline Фазовый переход & $\begin{array}{c}\text { Относительное } \\
\text { изменение объема, \% }\end{array}$ & Литература \\
\hline $\mathrm{Pd} \leftrightarrow \mathrm{PdH}_{0.6}$ & $\sim 10$ & {$[35]$} \\
$\mathrm{Y} \leftrightarrow \mathrm{YH}_{3}$ & 17 & {$[35,36]$} \\
$\mathrm{YH} \mathrm{H}_{2} \leftrightarrow \mathrm{YH}_{3}$ & 10 & {$[35,36]$} \\
$\mathrm{GdMg}_{\mathrm{GdMgH}_{2}}$ & 6 & {$[37]$} \\
$\mathrm{GdMgH}_{2} \leftrightarrow \mathrm{GdMgH}_{5}$ & 15 & {$[37]$} \\
$\mathrm{Mg} \leftrightarrow \mathrm{MgH}_{2}$ & 32 & {$[8,35]$} \\
$\mathrm{Mg}_{2} \mathrm{Ni} \leftrightarrow \mathrm{Mg}_{2} \mathrm{NiH}_{4}$ & 29 & {$[8,35]$}
\end{tabular}

объема компонентов магний-никелевого сплава при переходах $\mathrm{Mg} \leftrightarrow \mathrm{MgH}_{2}$ и $\mathrm{Mg}_{2} \mathrm{Ni} \leftrightarrow \mathrm{Mg}_{2} \mathrm{NiH}_{4}$ в обоих случаях равно 32\%. Поэтому периодические деформации, вызываемые различием изменения объемов слоев катализатора и активного слоя, приводят к разрушению более тонкого слоя палладия. При циклических процессах гидрирования-дегидрирования покрытого слоем палладия $\mathrm{Mg}-\mathrm{Y}$-сплава фазовый переход $\mathrm{Y} \leftrightarrow \mathrm{YH}_{2}$ имеет место только при первом переключении. При последующих переключениях имеет место переход $\mathrm{YH}_{2} \leftrightarrow \mathrm{YH}_{3}$ с отно- 

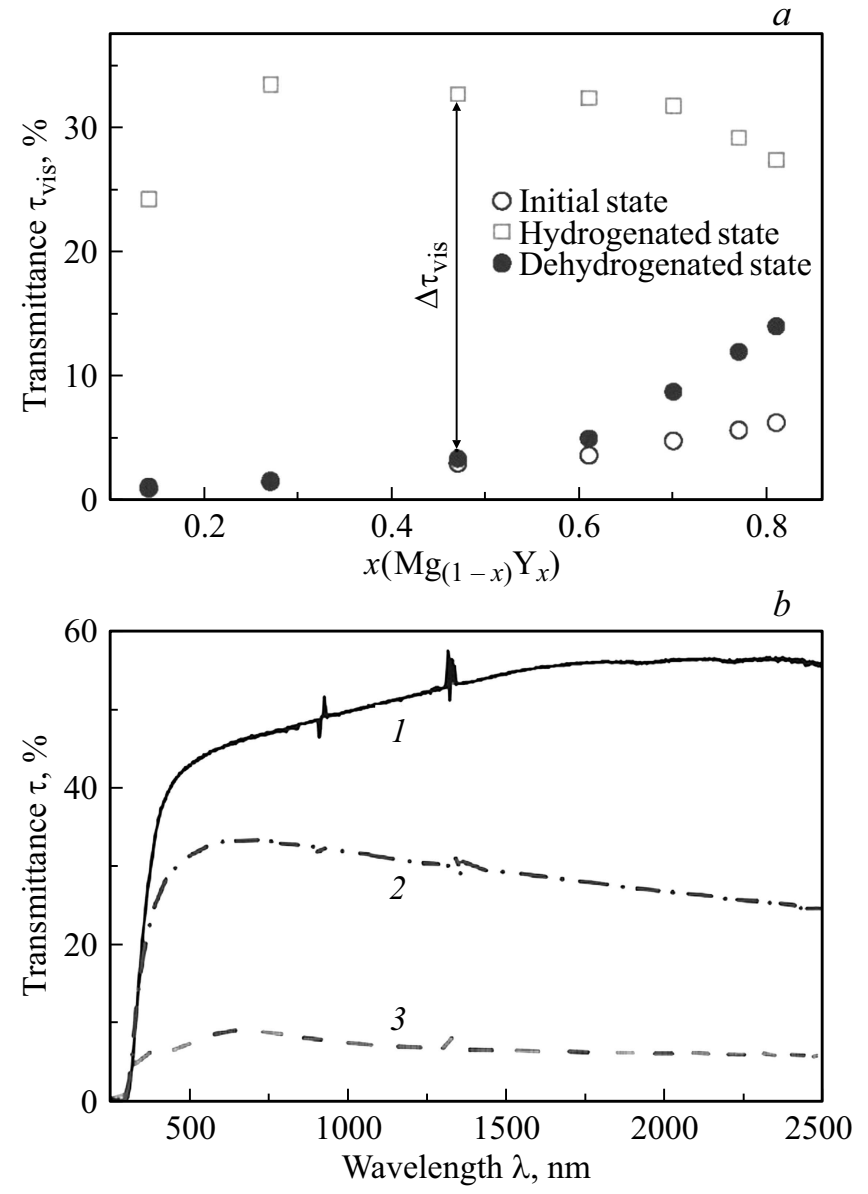

Рис. 8. Оптические характеристики $\mathrm{Mg}-$ Ү-пленки. Толщина активного слоя $\mathrm{Mg}-\mathrm{Y} 40 \mathrm{~nm}$, толщина Рd-пленки $7.5 \mathrm{~nm}$. $a-$ влияние молярной доли $x$ иттрия в сплаве $\mathrm{Mg}_{(1-x)} \mathrm{Y}_{x}$ на светопропускание $\tau_{\text {vis }}$ в исходном зеркальном (о) состоянии, после гидрирования в прозрачном $(\square)$ и после дегидрирования в зеркальном состояниях $(\bullet)$ [24]. $b-$ спектральные коэффициенты пропускания в прозрачном состоянии переключаемых зеркалстекол: 1 - стекло/ $\mathrm{Mg}_{4} \mathrm{Y}_{6} / \mathrm{Ta} / \mathrm{Pd} ; 2-$ стекло $/ \mathrm{Mg}_{4} \mathrm{Y}_{6} / / \mathrm{Pd} ; 3-$ стекло/ $\mathrm{Mg}_{4} \mathrm{Y}_{6} / \mathrm{Ta} / \mathrm{Pd}$ в зеркальном состоянии [25].

сительным изменением объема 10\%, равным изменению объема катализатора. Поэтому при увеличении содержания $\mathrm{Y}$ в составе сплава $\mathrm{Mg}-\mathrm{Y}$ относительное изменение объема такого материала также приближается к величине $10 \%$, равной аналогичной величине катализатора. Покрытые палладием пленки $\mathrm{Mg}-\mathrm{Y}$-сплава с высоким содержанием иттрия не должны разрушаться при многократных переключениях. Такие зеркала не деградируют после более 10000 переключений [24].

Светопропускание переключаемых зеркал-стекол с $\mathrm{Mg}-$ Ү-пленкой зависит от соотношения компонентов в сплаве и изменяется в диапазоне $\tau_{\text {vis }}=28-32 \%$ (рис. 8, a). Дополнительное увеличение светопропускания и долговечности переключаемых зеркал из $\mathrm{Mg}-\mathrm{Y}-$ сплава может быть достигнуто применением буферного металлического слоя. Такой слой позволяет уменьшить толщину слоя палладия. Из большого выбора металлов
(Ti, $\mathrm{Nb}, \mathrm{V}, \mathrm{Ta})$ лучшими свойствами обладает тантал Та [25]. По сравнению с остальными металлами он имеет наименьшее ослабление видимого света и самую высокую плотность. Каждый промежуточный слой снижает пропускание видимого света. Плотность Та и коэффициент диффузии водорода выше, чем у $\mathrm{Pd}$.

Пример данных для переключаемого зеркала с оптимизированным составом $\mathrm{Mg}-$ Ү-сплава и буферным слоем приведен на рис. 8, $b$ и 9. Применение слоя Та толщиной $2 \mathrm{~nm}$ полностью исключило диффузию между $\mathrm{Pd}$ и магниевым сплавом, что значительно увеличило циклическую стабильность устройства. Кроме того, использование слоя Та толщиной $2 \mathrm{~nm}$ позволило снизить толщину слоя палладия с 7.5 до $3 \mathrm{~nm}$ и тем самым увеличить светопропускание $\tau_{\text {vis }}$ от 32 до 44\%. Модуляция светопропускания $\Delta \tau_{\text {vis }} \sim 35 \%$ при циклических переключениях зеркала с буферным слоем Та более чем в два раза превышает аналогичную характеристику $\Delta \tau_{\text {vis }} \sim 15 \%$ зеркала без такого слоя. Интересно отметить, что эксперимент с циклическим переключением зеркала в количестве 10000 циклов продолжается непрерывно около полугода [25].

\section{Улучшение эксплуатационных характеристик переключаемых газохромных зеркал-стекол}

Для оценки эффективности умных окон на основе переключаемых зеркал-стекол был изготовлен опытный образец газохромного стеклопакета оконного размера $0.8 \times 1.2 \mathrm{~m}$ (рис. 10). Светопропускание стеклопакета
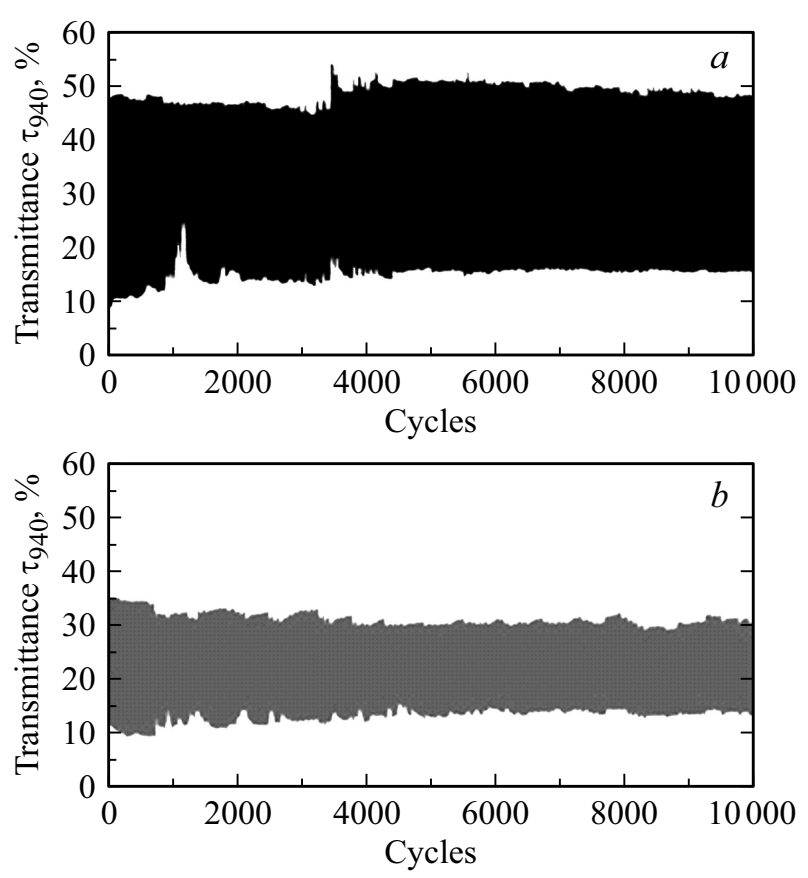

Рис. 9. Изменение коэффициента пропускания излучения на длине волны $\lambda=940 \mathrm{~nm}$ в ходе циклических переключений зеркал-стекол: $a-$ стекло/ $\mathrm{Mg}_{4} \mathrm{Y}_{6} / \mathrm{Ta} / \mathrm{Pd} ; \quad b-$ стекло $/ \mathrm{Mg}_{4} \mathrm{Y}_{6} / \mathrm{Pd}$ [25]. 


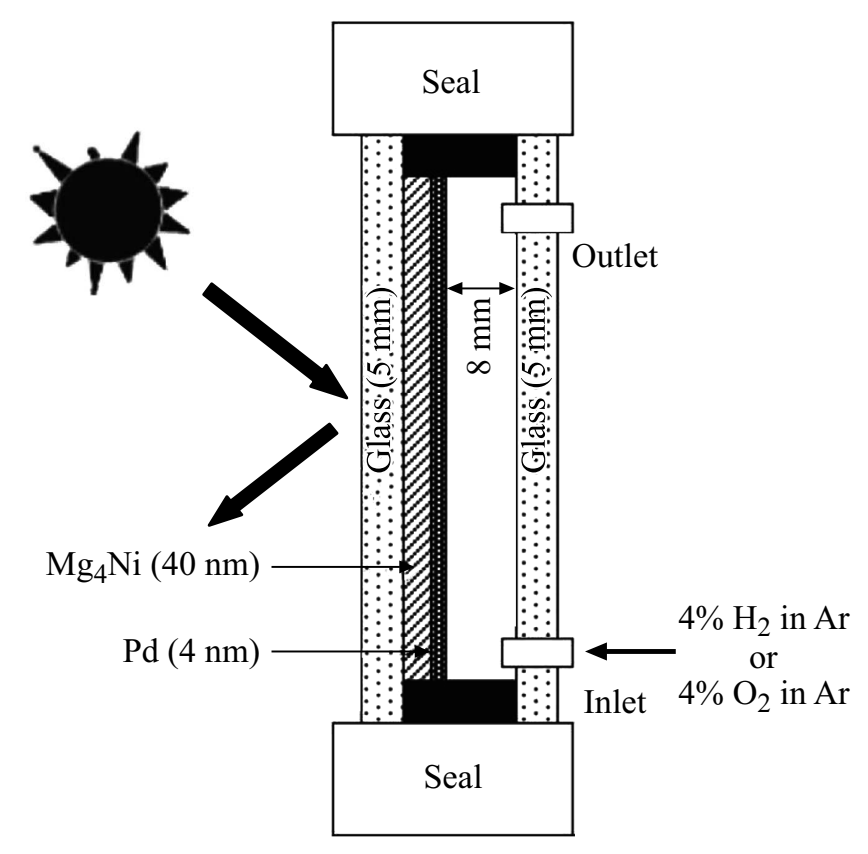

$a$

$b$

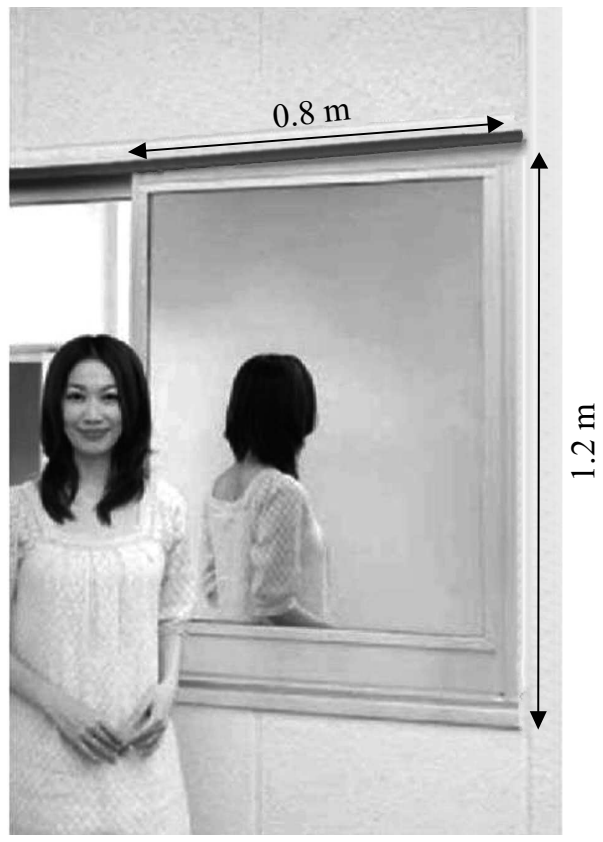

Mirror state

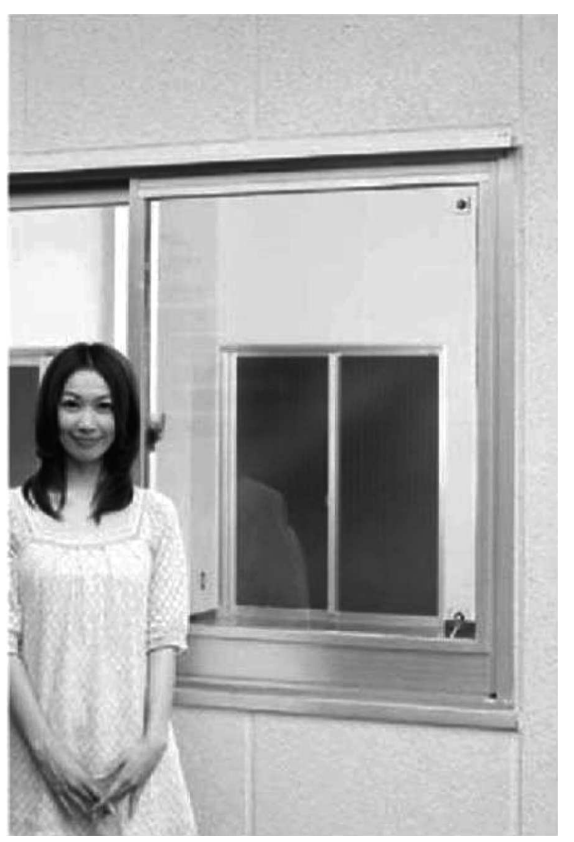

Transparent state

Рис. 10. Экспериментальный образец стеклопакета с переключаемым газохромным зеркалом-стеклом [38]: $a$ - схема стеклопакета; $b$ - фотографии стеклопакета в зеркальном и прозрачном состояниях.

в прозрачном состоянии $\tau_{\text {vis }}^{+}=32 \%$, в зеркальном состоянии $\tau_{\mathrm{vis}}^{-}=4 \%$. Умный и обычный однокамерный стеклопакет были установлены в одинаковые помещения. В солнечный летний день за счет переключения умного стеклопакета в зеркальное состояние экономия энергии на кондиционирование для поддержания одинаковой температуры в помещениях достигала $34 \%$. Однако в солнечный зимний день вследствие пониженного пропускания солнечной энергии через такое окно необходимы дополнительные затраты на отопление.
При этом дополнительные затраты на отопление в зимний период для помещения с таким окном превышают экономию энергии на кондиционирование в летний период. Для достижения положительного годового эффекта необходимы переключаемые окна со светопропусканием в прозрачном состоянии не менее $70 \%$ [38].

Увеличение светопропускания переключаемых зеркал-стекол достигнуто за счет использования просветляющего покрытия. Структура переключаемого зеркала- 


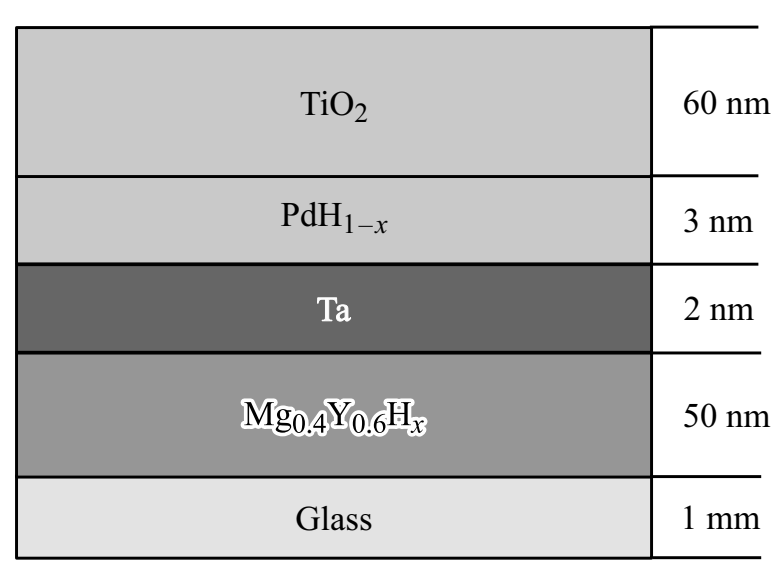

Рис. 11. Структура переключаемого газохромного зеркаластекла с просветляющим покрытием [27].

стекла с просветляющим покрытием изображена на рис. 11. Просветляющее покрытие из диоксида титана $\mathrm{TiO}_{2}$ толщиной $60 \mathrm{~nm}$ нанесено с использованием испарения под действием пучка электронов. За счет применения просветляющего покрытия светопропускание достигло величины $\tau_{\mathrm{vis}}^{+}=68 \%$ в прозрачном состоянии и $\tau_{\mathrm{vis}}^{-}=4 \%$ в зеркальном. При этом достигается другой положительный эффект - резко снижается отражательная способность зеркала от внутренней поверхности внутрь помещения. Стекла с такими значениями светопропускания можно использовать в коммерческих стеклопакетах.

Но для коммерческой реализации необходимо решить еще две проблемы:

- газоснабжение;

- промежуточные состояния.

В изображенном на рис. 10 стеклопакете с переключаемым газохромным зеркалом-стеклом размером $1 \times 1 \mathrm{~m}$ при расстоянии между стеклами $5 \mathrm{~mm}$ объем газа внутри стеклопакета равен 51. Проблема периодической замены этого газового объема для переключения состояния зеркала-стекла делает невозможной практическую реализацию такого устройства. Особенно в том случае, когда газовая смесь содержит взрывоопасный водород.

Ситуация меняется, если использовать переключаемое зеркало на гибкой пластиковой основе. Такие гибкие переключаемые электрохромные зеркала на пленке PTFE разработаны ранее [39]. Если переключаемое зеркало изготовить не на стекле, но на гибкой прозрачной пластиковой пленке и положить это изделие стороной с металлической активной пленкой на стекло, то между стеклом и активным слоем при наличии многочисленных точек контакта остается зазор около $0.1 \mathrm{~mm}$. Объем заполняющего этот зазор газа равен $100 \mathrm{ml}$ [40]. Конструкция такого устройства изображена на рис. 12.

При температуре воздуха $30^{\circ} \mathrm{C}$ и относительной влажности $50 \%$ содержание водяных паров в воздухе составляет $2 \%$ по объему. Необходимый для гидрирования активного слоя зеркала водород можно получить электролизом водяных паров по реакции [11]

$$
\mathrm{H}_{2} \mathrm{O}+\mathrm{e}^{-} \leftrightarrow \mathrm{H}+\mathrm{OH}^{-}
$$

Реакция электролиза идет на поверхности катализатора - палладия. Образующиеся атомы водорода диффундируют сквозь палладий и абсорбируются с образованием гидридов. Количества водяных паров, содержащихся в газовом зазоре толщиной $0.1 \mathrm{~mm}$, достаточно для гидрирования активной металлической пленки. Для электролиза водяных паров нужно к полимерной пленке приложить постоянное напряжение $3 \mathrm{~V}$. Фотография опытного образца размером $26 \times 37 \mathrm{~cm}$ приведена на рис. 13.

Гибкое переключаемое газохромное зеркало-стекло может быть нанесено на стекло произвольной искривленной формы, в том числе на автомобильное стекло. Это существенно расширяет область его применения.

Разработчики позаботились даже о том, чтобы в зеркальном состоянии зеркало давало бы рассеянное, но не зеркальное отражение при просмотре изнутри. Для это поверхность, на которую наносится активный металлический слой, изготавливается шероховатой [41]. При просмотре изнутри отраженное от зеркала изображение получается размытым. Но не сообщается, не получается ли таким же размытым изображение при просмотре изнутри через зеркало в прозрачном его состоянии. Это нежелательно и недопустимо.

Значительное улучшение циклической стабильности (до 15000 переключений) переключаемых зеркал-стекол достигнуто при использовании двухкомпонентного катализатора состава палладий-рутений $\mathrm{Pd}_{(1-x)} \mathrm{Ru}_{x}$ при $0.2 \leq x \leq 0.4$ [30]. Это обусловлено тем, что слой комбинированного катализатора более эффективно предотвращает окисление защитного слоя Та и слоя активного материала $\mathrm{Mg}_{4} \mathrm{Y}_{6}$. Кроме того, двухкомпонентный катализатор значительно сокращает продолжительность цикла переключения зеркала. Для зеркала-стекла с

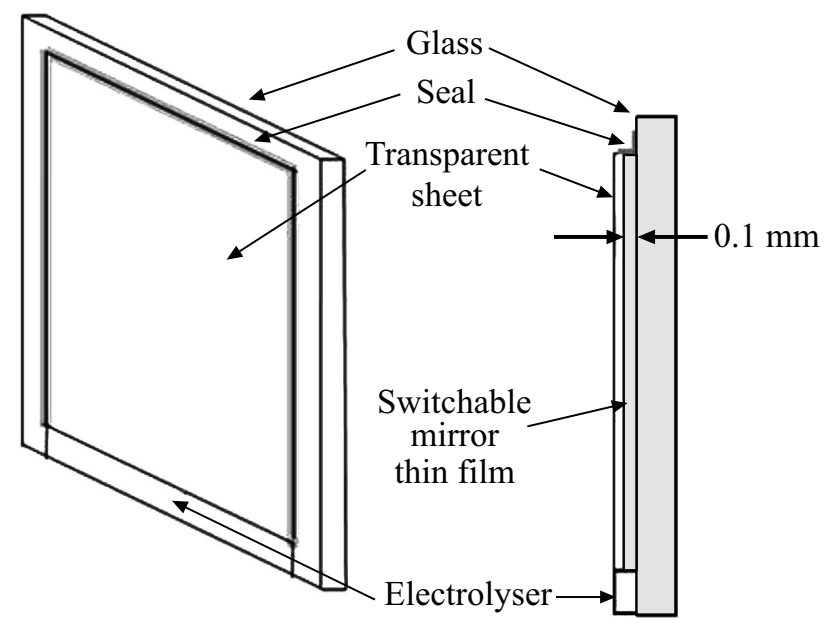

Рис. 12. Переключаемое газохромное зеркало-стекло с электролизным генерированием водорода из присутствующих в воздухе водяных паров [40]. 


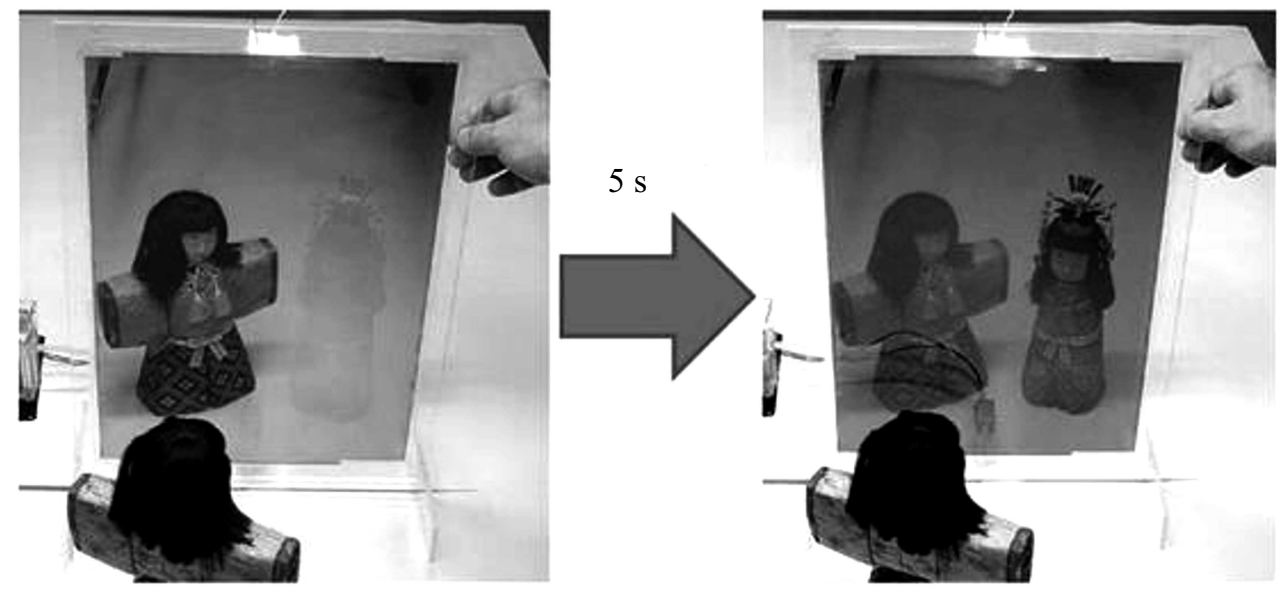

Рис. 13. Гибкое газохромное зеркало-стекло с электролизным генерированием водорода из присутствующих в воздухе водяных паров переключается при подключении электрической батареи [40].

палладиевым катализатором продолжительность процессов гидрирования/дегидрирования составляет около 3 и 600 с соответственно - величины отличаются примерно в 200 раз. Для устройства с комбинированным Pd$\mathrm{Ru}$-катализатором продолжительность этих процессов составляет примерно 10 и $150 \mathrm{~s}$ соответственно. При этом общее время цикла сокращается в 2-3 раза. Помимо отмеченных свойств, рутений примерно в 10 раз дешевле палладия.

\section{Пятое поколение материалов}

Широкое поле для исследований открывается после публикации первых обнадеживающих результатов по включению оксидов переходных металлов титана и ниобия $\left(\mathrm{TiO}_{2}\right.$ и $\left.\mathrm{Nb}_{2} \mathrm{O}_{5}\right)$ в состав основанного на магнии активного слоя [31,32]. Эти составы открывают пятое поколение переключаемых зеркал-стекол.

Диоксид титана доступен и обладает химической стойкостью и инертностью. Причина значительного улучшения оптических и структурных характеристик переключаемого зеркала-стекла с активным слоем из магния с оксидами переходных металлов заключается в том, что $\mathrm{TiO}_{2}$ и $\mathrm{Nb}_{2} \mathrm{O}_{5}$ являются катализаторами реакции магния с водородом и значительно улучшают кинетику сорбции/десорбции водорода в матрице $\mathrm{Mg}$.

Основные оптические свойства переключаемого зеркала-стекла с активным слоем $(1-x) \mathrm{Mg}-{ }_{x} \mathrm{TiO}_{2}$ приведены на рис. 14. На рис. 14, $a$ показано влияние молярной доли $\mathrm{TiO}_{2}$ на коэффициент светопропускания переключаемого зеркала-стекла в исходном зеркальном и прозрачном состояниях, а также в зеркальном состоянии после первого цикла гидрирования/дегидрирования. Наилучшие результаты по оптическим свойствам и циклической стабильности получены при $0.05 \leq x \leq 0.15$. При увеличении молярной доли $\mathrm{TiO}_{2}$ более 0.25 устройство становится полупрозрачным в обоих состояниях вследствие прозрачности пленки нанометровой толщины из диоксида титана.

Лучшими оптическими свойствами обладает активный слой состава ${ }_{0.9} \mathrm{Mg}-{ }_{0.1} \mathrm{TiO}_{2}$ (рис. $14, b$ ). В диапазоне длин волн видимого света коэффициент пропускания изменяется незначительно, поэтому проходящий сквозь такой слой свет не меняет спектрального состава. Модуляция светопропускания этого устройства $\Delta \tau_{\text {vis }}=36.1 \%$. В ходе циклических испытаний после 100 переключений динамический диапазон уменьшился на 3\%. При отсутствии защитного слоя между катализатором и активным материалом поверхность раздела между этими материалами осталась четко выраженной, и не обнаружено проявления взаимной диффузии $\mathrm{Mg}$ и $\mathrm{Pd}$. Кроме того, диоксид титана снижает деформационные и структурные изменения материалов активного слоя и слоя палладия. Оптические свойства переключаемого зеркала-стекла значительно улучшаются при замене диоксида $\mathrm{TiO}_{2}$ оксидом $\mathrm{Nb}_{2} \mathrm{O}_{5}$. При изготовлении активного слоя из сплава состава $0.99 \mathrm{Mg}_{-0.01} \mathrm{Nb}_{2} \mathrm{O}_{5}$ модуляция светопропускания возрастает до $\Delta \tau_{\text {vis }}=42.9 \%$ [32].

Приведенные результаты свидетельствуют о том, что разработка переключаемого газохромного зеркаластекла близка к стадии практической реализации в виде коммерческого продукта.

Осталось решить последнюю проблему - обеспечить несколько промежуточных состояний.

Переключаемое газохромное зеркало-стекло имеет только два состояния: прозрачное и зеркальное. Достигнутые значения светопропускания в этих состояниях $\tau_{\mathrm{vis}}^{+}=70$ и $\tau_{\mathrm{vis}}^{-}=8 \%$. При переключении из прозрачного в зеркальное состояние даже при солнечном освещении в помещении станет слишком темно. Поэтому необходимо несколько промежуточных состояний со светопропусканием между 8 и 70\%.

Но как это обеспечить практически - вот вопрос. Вполне возможно, что промежуточные состояния тео- 

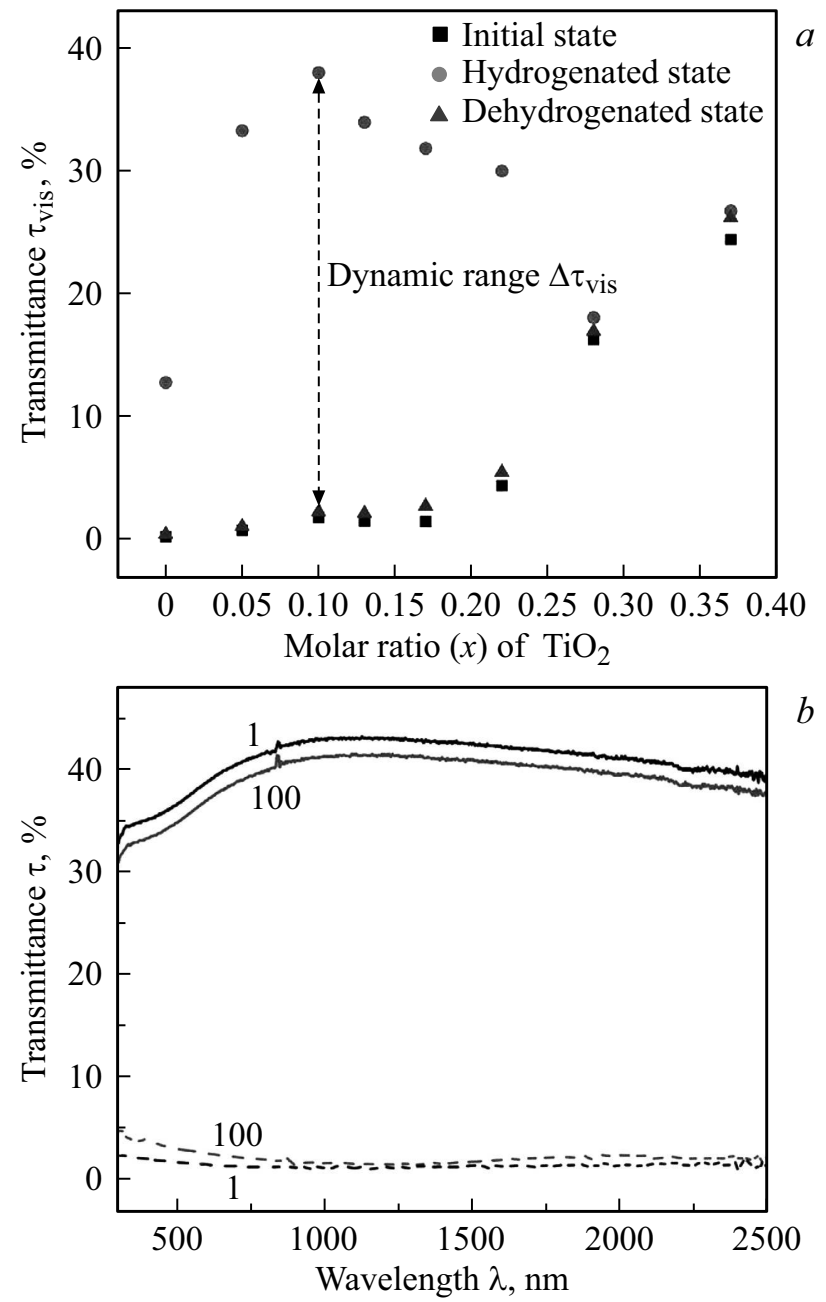

Рис. 14. Оптические характеристики пленки активного материала ${ }_{(1-x)} \mathrm{Mg}-{ }_{x} \mathrm{TiO}_{2}$ толщиной $50 \mathrm{~nm}$, покрытой пленкой $\mathrm{Pd}$ толщиной $5 \mathrm{~nm}$ [31]: $a-$ влияние молярной доли х диоксида титана в составе ${ }_{(1-x)} \mathrm{Mg}_{-} \mathrm{TiO}_{2}$ на светопропускание $\tau_{\text {vis }}$ в

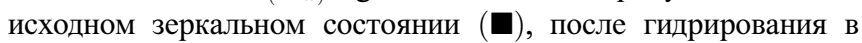
прозрачном (•) и после дегидрирования в зеркальном состояниях $(\boldsymbol{\Delta}) ; b-$ спектральные коэффициенты пропускания пленки с оптимальным составом ${ }_{0.9} \mathrm{Mg}_{-0.1} \mathrm{TiO}_{2}$ активного слоя в зеркальном (штриховые линии) и прозрачном (сплошные линии) состояниях в 1-м цикле гидрирования/дегидрирования (1) и после 100 таких циклических переключений (100).

ретически можно обеспечить при очень тонком регулировании концентрации подводимого водорода, и реализовать это можно именно только при электролизе. Однако до сих пор не зафиксировано ни одного промежуточного состояния переключаемых газохромных зеркал, кроме самых первых результатов на рис. 2.

\section{Переключаемые электрохромные зеркала-стекла с твердым электролитом}

Сразу после обнаружения явления газохромного переключения зеркал-стекол на гидридах металлов было предложено для переключения использовать электрохимические ячейки с жидкостным [11] и твердым [12] электролитом. Для практического применения в умных окнах можно использовать электрохимические ячейки только с твердым электролитом - переключаемые электрохромные зеркала-стекла с твердым электролитом.

В изображенном на рис. 15 первом образце такого устройства в качестве активного материала использовали магний-гадолиниевый сплав. Устройство содержит стекло с прозрачным электропроводящим покрытием ITO (ITO - IndiumTinOxide - легированный оловом оксид индия $\mathrm{In}_{2} \mathrm{O}_{3}: \mathrm{Sn}$ ), оптический переключатель слой $\mathrm{Mg}-\mathrm{Gd}-$ сплава, слой палладия $\mathrm{Pd}$ - инжектор протонов, твердый электролит из гидрата оксида циркония $\mathrm{ZrO}_{2} \cdot \mathrm{H}_{2} \mathrm{O}$ - проводник протонов, источник протонов из электрохромного триоксида вольфрама $\mathrm{H}_{x} \mathrm{WO}_{3}$ и ITO - покрытие. Источник протонов $\mathrm{H}_{x} \mathrm{WO}_{3}$ является дополнительным к активному слою электрохромным материалом, переключаемым из прозрачного состояния в голубое при инжекции в него протонов.

В нейтральном отключенном состоянии устройство находится в зеркальном металлическом состоянии. Под действием подаваемого на активный $\mathrm{Mg}-\mathrm{Gd}$-слой отрицательного напряжения $-3 \mathrm{~V}$ протоны из источника протонов $\mathrm{H}_{x} \mathrm{WO}_{3}$ инжектируются в $\mathrm{Mg}-\mathrm{Gd}$-слой. Этот слой становится прозрачным и одновременно становится прозрачным источник протонов слой $\mathrm{WO}_{3}$. В этом состоянии все слои устройства прозрачны, кроме слоя гидрида палладия. При переключении из зеркального в прозрачное состояние светопропускание возрастает от 0 до $\sim 20 \%$.

Концентрация атомов водорода в активном переключаемом слое регулируется подаваемым напряжением, что дает возможность создавать промежуточные оптические состояния между зеркальным и прозрачным. Одно такое промежуточное состояние при напряжении $-2 \mathrm{~V}$ было реализовано.

Исследование этого устройства подтвердило возможность реализации переключаемого зеркала-стекла с

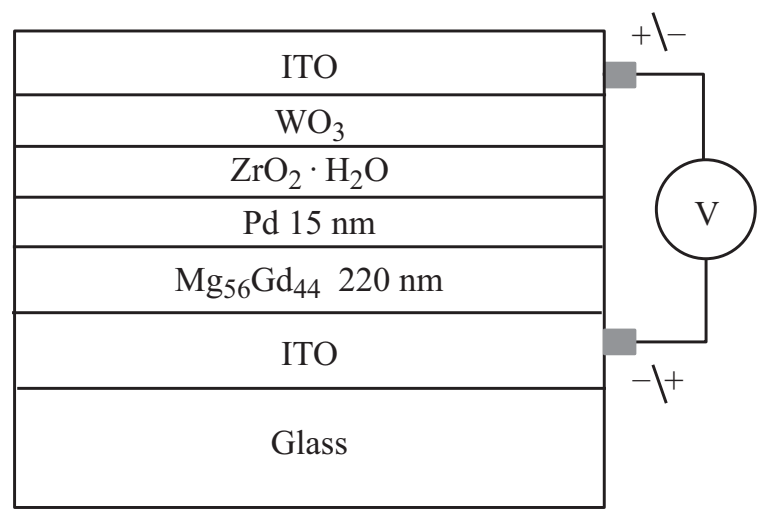

Рис. 15. Схема электрохромного переключаемого зеркаластекла с твердым электролитом [12]. При отрицательном напряжении $-3 \mathrm{~V}$ на активном слое $\mathrm{Mg}-\mathrm{Gd}$ все слои прозрачны, кроме слоя гидрида палладия $\mathrm{PdH}_{0.6}$. 
твердым электролитом. Причем такое устройство имеет примерно такие же оптические свойства и обладает также и всеми недостатками, что и разработанные к тому времени аналогичные газохромные устройства. Но создавать зеркала с твердым электролитом значительно сложнее вследствие наличия дополнительных слоев. Поэтому дальнейшие разработки переключаемых зеркал с твердым электролитом были отложены до лучших времен, пока не будут достигнуты удовлетворительные результаты с газохромными переключаемыми зеркалами. Но поскольку в первое десятилетие такие результаты достигнуты не были, поэтому к исследованию переключаемых зеркал с твердым электролитом больше не возвращались.

Второй десятилетний период продолжается с 2007 г. В это время только одна группа японских исследователей из National Institute of Advanced Industrial Science and Technology (AIST) настойчиво продолжает разработку переключаемых зеркал-стекол с целью доводки их до практической реализации в виде коммерческих умных окон. Поскольку в это время считается, что основным типом переключаемых зеркал для таких окон могут быть только зеркала-стекла с твердым электролитом, то, уделяя основное внимание улучшению оптических свойств и долговечности газохромных переключаемых зеркал-стекол, эти исследователи периодически проверяют вновь полученные результаты на переключаемых электрохромных зеркалах с твердым электролитом.

В табл. 3 приведены основные достижения в разработке переключаемых электрохромных зеркал-стекол с твердым электролитом.

В работе [42] приведены результаты исследования переключаемого зеркала-стекла с твердым электролитом, многослойная структура которого описывается формулой $\mathrm{Mg}_{4} \mathrm{Ni} / \mathrm{Pd} / \mathrm{Ta}_{2} \mathrm{O}_{5} / \mathrm{H}_{x} \mathrm{WO}_{3} / \mathrm{ITO} /$ стекло. Отдельные слои выполняют функции: слой $\mathrm{Mg}_{4} \mathrm{Ni}$ толщиной $40 \mathrm{~nm}$ - переключаемое зеркало, Pd (4 nm) - инжектор протонов; $\mathrm{Ta}_{2} \mathrm{O}_{5}(400 \mathrm{~nm})$ - твердый электролит, проводник протонов; $\mathrm{H}_{x} \mathrm{WO}_{3}(500 \mathrm{~nm})$ - источник протонов - переключаемый электрохромный абсорбирующий слой; ITO - прозрачное электропроводящее покрытие.

При изготовлении устройства использовали готовое стекло со слоями ITO и $\mathrm{WO}_{3}$. Затем вакуумным магнетронным напылением наносили последовательно все остальные слои. При этом перед нанесением слоя $\mathrm{Pd}$ в слой $\mathrm{WO}_{3}$ через слой $\mathrm{Ta}_{2} \mathrm{O}_{5}$ инжектировали протоны методом пропитывания серной кислотой концентрации $0.5 \mathrm{M}$.

При отсутствии напряжения устройство находится в зеркальном состоянии. При подаче отрицательного напряжения на активный слой $\mathrm{Mg}_{4} \mathrm{Ni}$ относительно ITOпокрытия протоны перемещаются из источника протонов слоя $\mathrm{H}_{x} \mathrm{WO}_{3}$ в активный слой $\mathrm{Mg}_{4} \mathrm{Ni}$, в котором образуются гидриды $\mathrm{MgH}_{2}$ и $\mathrm{Mg}_{2} \mathrm{NiH}_{4}$. В результате этого активный слой и слой $\mathrm{H}_{x} \mathrm{WO}_{3}$ и, следовательно, все устройство переходят в прозрачное состояние. Переключение в прозрачное состояние описывается следующими реакциями: на катоде в активном слое

$$
\begin{aligned}
\mathrm{Mg}_{2} \mathrm{Ni}_{\text {[зеркальное состояние }]}+ & 4 \mathrm{H}^{+}+4 \mathrm{e}^{-}= \\
= & \mathrm{Mg}_{2} \mathrm{NiH}_{4[\text { прозрачное состояние }]} \\
\mathrm{Mg}_{[\text {зеркальное состояние }]}+ & 2 \mathrm{H}^{+}+2 \mathrm{e}^{-}= \\
= & \mathrm{MgH}_{2[\text { прозрачное состояние }]} ;
\end{aligned}
$$

и на аноде, в слое $\mathrm{H}_{x} \mathrm{WO}_{3}$

$$
\begin{aligned}
& \mathrm{H}_{x} \mathrm{WO}_{3[\text { окрашенное состояние }]}= \\
& \quad=\mathrm{WO}_{3 \text { [прозрачное состояние }]}+x \mathrm{H}^{+}+x \mathrm{e}^{-},
\end{aligned}
$$

где обычно $0.05<x<0.4$.

Во всех последующих работах авторы использовали такую же технологию изготовления изделий и примерно такие же толщины слоев. В готовом изделии слой переключаемого зеркала $\mathrm{Mg}_{4} \mathrm{Ni}$ оказался снаружи и подвержен воздействию окружающего воздуха.

После 2000 циклических переключений отмечено значительное ухудшение оптических свойств. Выявлены две причины:

- разрушение наружной поверхности слоя $\mathrm{Mg}_{4} \mathrm{Ni}$ вследствие деформаций, вызванных различием в объемном расширении слоев $\mathrm{Mg}_{4} \mathrm{Ni}$ и $\mathrm{Pd}$,

- диффузия Ni и $\mathrm{Pd}$ в слой твердого электролита $\mathrm{Ta}_{2} \mathrm{O}_{5}$.

В следующем изделии $\mathrm{Mg}_{4} \mathrm{Ni} / \mathrm{Pd} / \mathrm{Al} / \mathrm{Ta}_{2} \mathrm{O}_{5} / \mathrm{H}_{x} \mathrm{WO}_{3} /$ ITO/стекло для устранения диффузии $\mathrm{Ni}$ и $\mathrm{Pd}$ в слой твердого электролита $\mathrm{Ta}_{2} \mathrm{O}_{5}$ между слоями $\mathrm{Ta}_{2} \mathrm{O}_{5}$ и $\mathrm{Pd}$ был размещен буферный слой алюминия толщиной $2 \mathrm{~nm}$ [43]. Слой алюминия хорошо пропускает протоны. Применение буферного слоя позволило продлить число переключений зеркала до более 5000 без заметного ухудшения оптических свойств. При этом светопропускание в прозрачном состоянии после 3000 переключений остается практически неизменным $\sim 40 \%$, но в зеркальном состоянии светопропускание постепенно возрастает от 0 до $\sim 10 \%$. Причиной этого является окисление магния в поверхностном слое за счет кислорода атмосферного воздуха. Для предотвращения поступления кислорода из воздуха предложено использовать поверхностное прозрачное покрытие.

Магниево-никелевый сплав в переключаемом зеркале в прозрачном состоянии придает желтоватый оттенок проходящему свету. Это является существенным препятствием для использования переключаемых зеркал такого состава в умных окнах. В работе [44] приведены результаты исследования переключаемого зеркала с твердым электролитом с использованием $\mathrm{Mg}$-Ті-сплава в активном слое. Лучшими оптическими свойствами обладает сплав состава $\mathrm{Mg}_{88} \mathrm{Ti}_{12}$. Такое зеркало в прозрачном состоянии оптически нейтрально и не придает оттенка проходящему через него свету. Поэтому авторы считают такой сплав наиболее подходящим для практического 
Таблица 3. Улучшение свойств переключаемых электрохромных зеркал-стекол на гидридах металлов с твердым электролитом по мере применения новых материалов (результаты приведены в хронологическом порядке)

\begin{tabular}{|c|c|c|c|c|c|c|c|c|c|c|c|}
\hline Год & $\begin{array}{c}\text { Защитный } \\
\text { слой }\end{array}$ & $\begin{array}{c}\text { Активный } \\
\text { слой }\end{array}$ & $\begin{array}{c}\text { Инжектор } \\
\text { протонов }\end{array}$ & $\begin{array}{c}\text { Буферный } \\
\text { слой }\end{array}$ & $\begin{array}{c}\text { Твердый } \\
\text { электролит }\end{array}$ & $\begin{array}{l}\text { Источник } \\
\text { протонов }\end{array}$ & $\begin{array}{c}\text { Прозрачное } \\
\text { покрытие }\end{array}$ & $\tau_{\mathrm{vis}}, \%$ & $\begin{array}{l}\text { Число } \\
\text { циклов }\end{array}$ & $\begin{array}{c}\text { Органи- } \\
\text { зация }\end{array}$ & $\begin{array}{l}\text { Литера- } \\
\text { тура }\end{array}$ \\
\hline 1999 & - & $\mathrm{Mg}_{56} \mathrm{Gd}_{44}$ & $\mathrm{Pd}$ & - & $\mathrm{ZrO}_{2} \cdot \mathrm{H}_{2} \mathrm{O}$ & $\mathrm{H}_{x} \mathrm{WO}_{3}$ & ITO & $\sim 20$ & - & III & [12] \\
\hline 2007 & - & $\mathrm{Mg}_{4} \mathrm{Ni}$ & $\mathrm{Pd}$ & - & $\mathbf{T a}_{2} \mathbf{O}_{5}$ & $\mathrm{H}_{x} \mathrm{WO}_{3}$ & ITO & $\sim 40$ & 2000 & IV & {$[42]$} \\
\hline 2007 & - & $\mathrm{Mg}_{4} \mathrm{Ni}$ & $\mathrm{Pd}$ & Al & $\mathrm{Ta}_{2} \mathrm{O}_{5}$ & $\mathrm{H}_{x} \mathrm{WO}_{3}$ & ITO & $\sim 40$ & 5000 & IV & [43] \\
\hline 2008 & - & $\mathbf{M g}_{88} \mathbf{T i}_{12}$ & $\mathrm{Pd}$ & - & $\mathrm{Ta}_{2} \mathrm{O}_{5}$ & $\mathrm{H}_{x} \mathrm{WO}_{3}$ & ITO & $\sim 36$ & 1000 & IV & {$[44]$} \\
\hline 2010 & - & $\mathrm{Mg}_{4} \mathrm{Ni}$ & $\mathbf{P d}_{92} \mathbf{A g}_{8}$ & $\mathrm{Al}$ & $\mathrm{Ta}_{2} \mathrm{O}_{5}$ & $\mathrm{H}_{x} \mathrm{WO}_{3}$ & ITO & $\sim 40$ & 500 & IV & {$[45]$} \\
\hline 2014 & - & $\mathrm{Mg}-\mathrm{Zr}-\mathrm{Ni}$ & $\mathrm{Pd}$ & $\mathrm{Al}$ & $\mathrm{Ta}_{2} \mathrm{O}_{5}$ & $\mathrm{H}_{x} \mathrm{WO}_{3}$ & ITO & $30-43$ & - & IV & {$[26]$} \\
\hline 2014 & ППП & $\mathrm{Mg}_{4} \mathrm{Ni}$ & $\mathrm{Pd}$ & $\mathrm{Al}$ & $\mathrm{Ta}_{2} \mathrm{O}_{5}$ & $\mathrm{H}_{x} \mathrm{WO}_{3}$ & ITO & $\sim \mathbf{5 0}$ & - & IV & {$[46,47]$} \\
\hline
\end{tabular}

Примечание. 1. Впервые примененные материалы и наиболее значительные результаты выделены жирным шрифтом.

2. III - Lawrence Berkeley National Laboratory (LBL), USA; IV — National Institute of Advanced Industrial Science and Technology (AIST), Japan.

3. ППП - прозрачное полимерное покрытие - полимерный защитный слой из ПВХ, политетрафторэтилена, полициклоолефина или фотополимеризуемого полимера, которое препятствует окислению $\mathrm{Mg}$ в активном слое и значительно продлевает срок службы при повышенных температуре и влажности.

использования. Однако после 1000 переключений отмечено значительное ухудшение оптических свойств. Причины те же, что и в ранее исследованном образце [42].

Особо следует отметить результаты исследования влияния состава и толщины инжектирующего протоны слоя $\mathrm{Pd}$ на оптические свойства переключаемого зеркала-стекла с твердым электролитом [45]. Дело в том, что в одной из первых работ по исследованию газохромных переключаемых зеркал [16] было высказано предположение о том, что в переключаемых зеркалах с твердым электролитом слой каталитического $\mathrm{Pd}$ не нужен и может быть опущен, поскольку ионы водорода имеются в твердом электролите. Уменьшение толщины слоя $\mathrm{Pd}$ от 8 до $0 \mathrm{~nm}$ увеличивает светопропускание переключаемого зеркала в прозрачном состоянии, но при этом очень быстро сокращается долговечность зеркала. Без слоя $\mathrm{Pd}$ зеркало перестает переключаться после нескольких циклов. Оптимальная толщина слоя $\mathrm{Pd}$ равна $4 \mathrm{~nm}$. Было установлено, что добавление к палладию серебра в концентрации около $8 \%$ не ухудшает свойства слоя, но позволяет заменить часть ценного Pd на серебро.

Последним исследованным этапом по улучшению свойств переключаемых зеркал-стекол с твердым электролитом является применение прозрачных полимерных покрытий на внешней поверхности. Такие покрытия предохраняют $\mathrm{Mg}$ в поверхностном слое от окисления кислородом атмосферного воздуха. Результаты исследования переключаемых зеркал-стекол с полимерным покрытием приведены в работах [46,47]. Структура таких устройств изображена на рис. 16. Толщина всех слоев без стекла около $10 \mu \mathrm{m}$. Некоторые результаты изображены на рис. 17 и 18.

На рис. 17 показано изменение оптических свойств устройства при изменении напряжения от -5 до $+5 \mathrm{~V}$. Переключение осуществляется очень быстро. При подаче напряжения $-5 \mathrm{~V}$ на активный слой в момент времени $t=5 \mathrm{~s}$ его светопропускание изменяется от

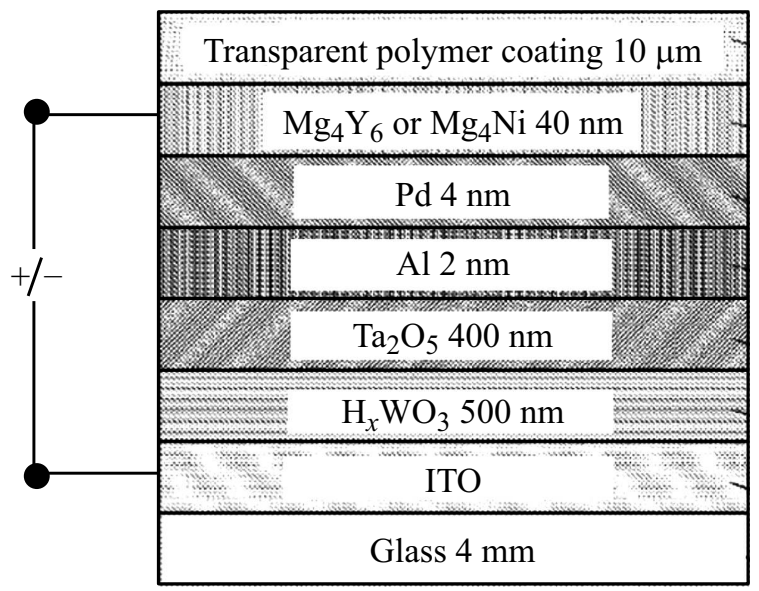

Рис. 16. Структура переключаемого электрохромного зеркала-стекла с твердым электролитом [47].

$0.1 \%$ в зеркальном состоянии до $\sim 52 \%$ в прозрачном в течение $25 \mathrm{~s}$. При подаче напряжения противоположной полярности при $t=65 \mathrm{~s}$ устройство переключается от прозрачного к зеркальному состоянию в пределах $20 \mathrm{~s}$. Добавление прозрачного полимерного покрытия увеличивает диапазоны изменения как пропускательной, так и отражательной способностей устройства.

На рис. 18 показаны спектральные пропускательная и отражательная характеристики устройства в зеркальном и прозрачном состояниях. Устройство обладает высокой пропускательной способностью в диапазоне видимого света от 380 до $780 \mathrm{~nm}$. Но имеет характерную для сплава $\mathrm{Mg}_{4} \mathrm{Ni}$ уменьшенную пропускательную способность на левом краю (от 380 до $500 \mathrm{~nm}$ ) этого диапазона, что придает желтоватый оттенок проходящему через него свету.

Как пропускательная $\tau$, так и особенно отражательная $\rho$ характеристики в прозрачном состоянии имеют волнообразный характер. Аналогичный вид эти ха- 
рактеристики имеют и в других работах $[12,26,44]$. У газохромных зеркал-стекол нет таких волнообразных колебаний оптических характеристик (рис. 3, 4, 6 и 8). Необходимо отметить также, что в электрохромном переключаемом зеркале-стекле с твердым электролитом имеется ITO-покрытие, и поэтому оптические свойства всего устройства в прозрачном состоянии в диапазоне длин волн $\lambda>1000 \mathrm{~nm}$ определяются оптическими свойствами ITO-покрытия. При увеличении длины волны в диапазоне $1000<\lambda<3000 \mathrm{~nm}$ коэффициент пропускания ІТО-покрытия $\tau$ быстро уменьшается от $\sim 75$ до $\sim 3 \%$, а коэффициент отражения $\rho$ быстро возрастает от $\sim 10$ до $\sim 75 \%$. Поэтому в прозрачном состоянии в этом диапазоне длин волн изменение оптических характеристик $\tau, \rho$ всего устройства должно соответствовать монотонному изменению характеристик ITO-покрытия.

Особенно существенное влияние полимерное покрытие оказывает на способность длительное время сохранять зеркалом свои свойства в условиях увеличенной до
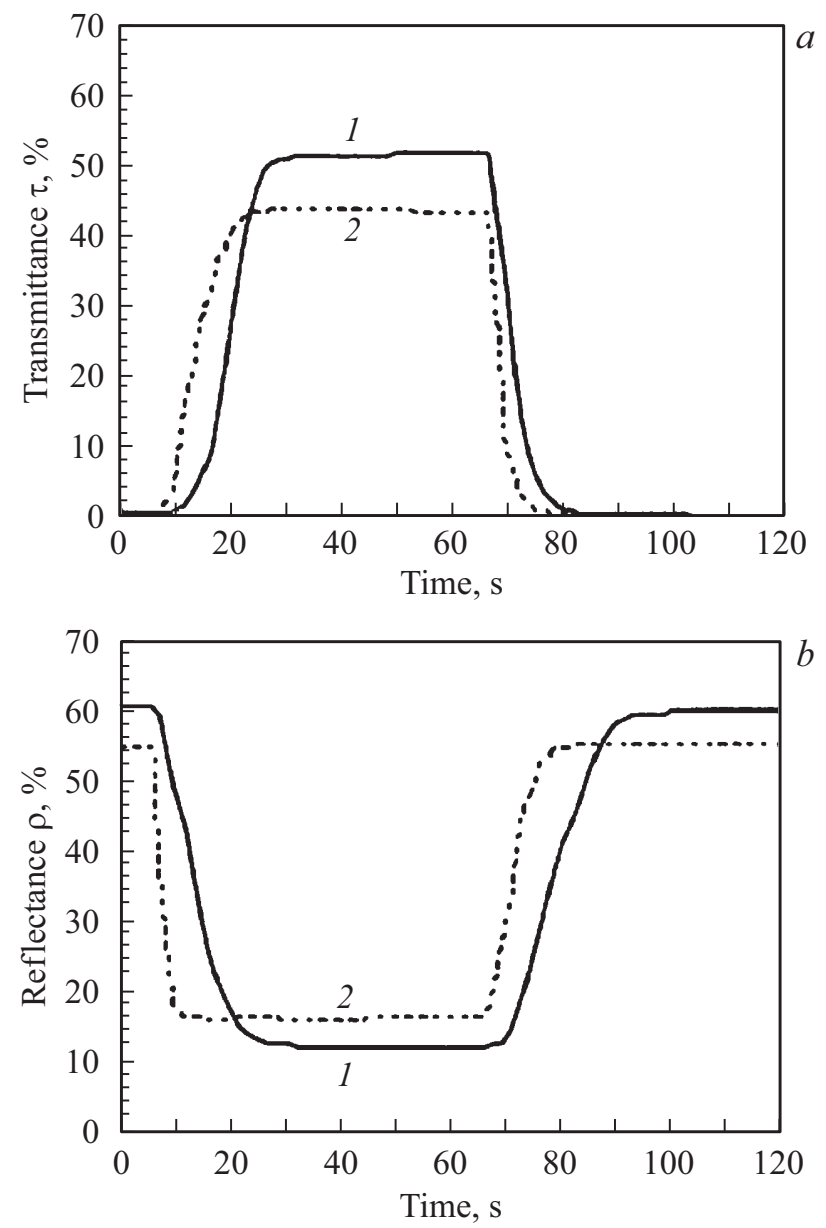

Рис. 17. Влияние прозрачного полимерного покрытия на изменение пропускания $(a)$ и отражения $(b)$ излучения с длиной волны $\lambda=670 \mathrm{~nm}$ электрохромного переключаемого зеркала-стекла с твердым электролитом при переключении напряжения на устройстве от -5 до $+5 \mathrm{~V}$ [47]: 1 - зеркалостекло с полимерным прозрачным покрытием; 2 - зеркалостекло без такого покрытия.
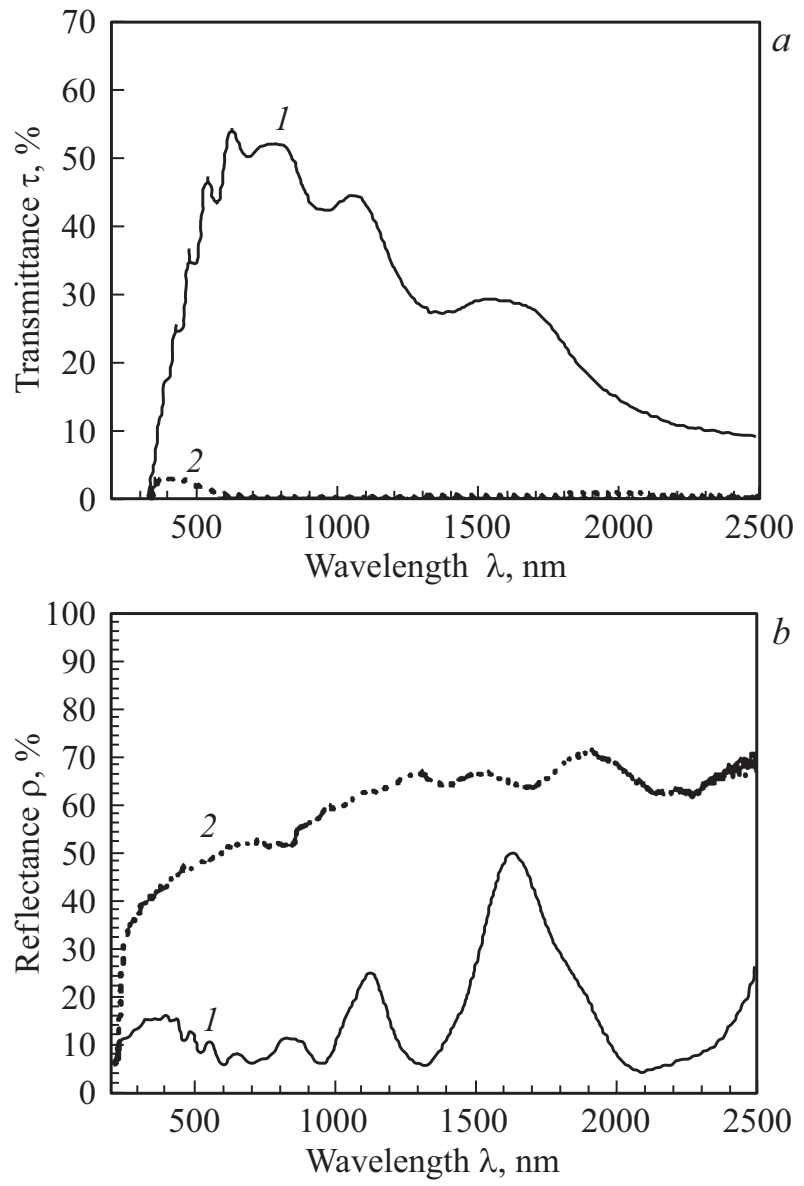

Рис. 18. Спектральные коэффициенты пропускания (a) и отражения $(b)$ электрохромного переключаемого зеркала-стекла с твердым электролитом и прозрачным полимерным покрытием в прозрачном (1) и зеркальном (2) состояниях [47].

$40^{\circ} \mathrm{C}$ температуры и увеличенной до $80 \%$ относительной влажности воздуха.

Приведенные в табл. 3 характеристики электрохромных переключаемых зеркал-стекол не удовлетворяют требованиям для практической реализации в умных окнах:

- они должны сохранять свои оптические свойства в течение не менее 10000 переключений;

- наличие желтого оттенка в пропускаемом свете;

- недостаточно светопропускание - оно не превышает $50 \%$.

Необходимо отметить также, что ни в одном из исследованных японскими разработчиками устройств не были реализованы промежуточные между зеркальным и прозрачным состояния переключаемых зеркал-стекол.

Первые два из указанных недостатков в газохромных переключаемых зеркалах-стеклах были устранены в результате использования в качестве материала для активного слоя магний-иттриевого сплава $\mathrm{Mg}_{4} \mathrm{Y}_{6}$. Повышение светопропускания до $\sim 70 \%$ было достигнуто 


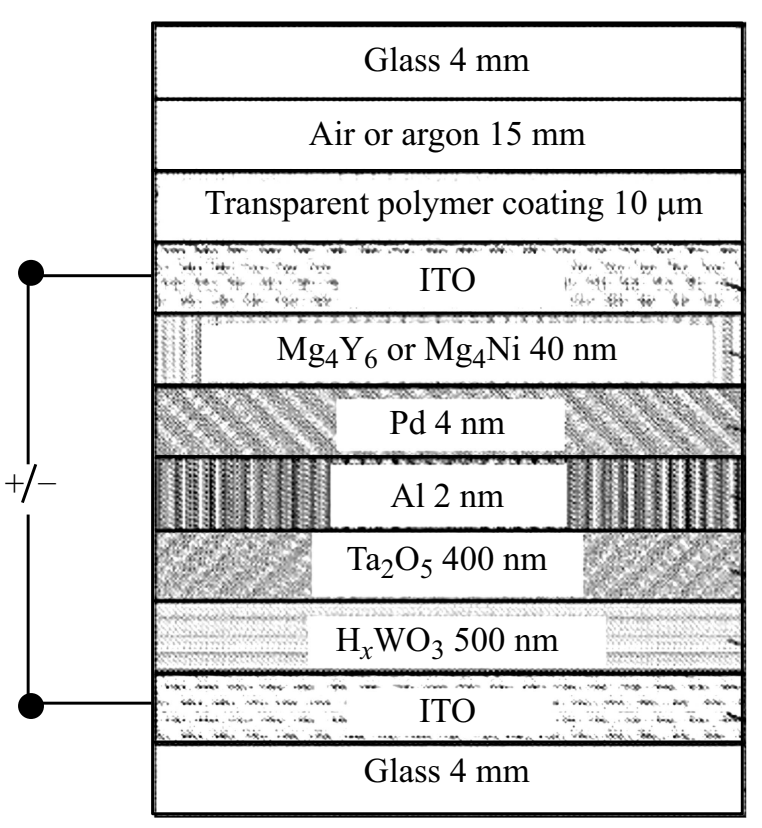

Рис. 19. Структура стеклопакета с переключаемым электрохромным зеркалом-стеклом с твердым электролитом [47].

добавлением просветляющего покрытия диоксида титана $\mathrm{TiO}_{2}$ толщиной $60 \mathrm{~nm}$.

Предлагаемая конструкция стеклопакета для умного окна с переключаемым электрохромным зеркаломстеклом с твердым электролитом приведена на рис. 19. Нужно отметить, что здесь отсутствует просветляющее покрытие.

Можно надеяться, что применение всех новых материалов и технических решений, исследованных при разработке газохромных переключаемых зеркал-стекол, в конструкции переключаемого электрохромного зеркаластекла с твердым электролитом позволит довести характеристики таких изделий до уровня, соответствующего практической реализации в умных окнах. Причем за счет тонкой регулировки напряжения можно обеспечить промежуточные состояния между зеркальным и прозрачным. Для коммерческой реализации таких окон определяющим фактором будет только их стоимость.

\section{Список литературы}

[1] Майоров B.A. // Светопрозрачные конструкции. 2016. № 1. C. $21-35$.

[2] Майоров В.А. // Светопрозрачные конструкции. 2016. № 2. C. $8-20$.

[3] Майоров В.A. // Опт. и спектр. 2018. Т. 124. № 4. C. 559-573. doi 10.21883/OS.2018.04.45759.240-17

[4] Майоров В.А. // Опт. и спектр. 2019. Т. 126. № 4. C. 495-514. doi 10.21883/OS.2019.04.47521.264-18

[5] Huiberts J.N., Griessen R., Rector J.H., Wijngaargen R.J., Dekker J.P., deGroot D.G., Koeman N.J. // Nature. 1996. V. 380. P. 231-234. doi 10.1038/380231a0
[6] Griessen R., Giebels I.A.M.E., Dam B. Optical Properties of Metal-hydrides: Switchable Mirrors. 2004. 75 p. http://www.nat.vu.nl/en/Images/ ReviewSwitchableMirrors10AUG04_tcm208-85550.pdf

[7] van der Sluis P., Ouwerkerk M., Duine P.A. // Appl. Phys. Lett. 1997. V. 70. P. 3356-3358. doi 10.1063/1.119169

[8] Richardson T.J., Slack J.L., Armitage R.D., Kostecki R., Farangis B., Rubin M.D. // Appl. Phys.Lett. 2001. V. 78. P. 3047-3049. doi 10.1063/1.1371959

[9] Richardson T.J., Slack J.L., Farangis B., Rubin M.D. // Appl. Phys. Lett. 2002. V. 80. P. 1349-1351. doi 10.1063/1.1454218

[10] Yoshimura K., Yamada Y., Okada M. // Appl. Phys. Lett. 2002. V. 81. P. 4709-4711. doi 10.1063/1.1530378

[11] Notten P.H.L., Kremers M., Griessen R. // J. Electrochem. Society. 1996. V. 143. P. 3348-3353. doi 10.1149/1.1837210

[12] Armitage R., Rubin M., Richardson T., O'Brien N., Chen Y. // Appl. Phys. Lett. 1999. V. 75. P. 1863-1865. doi $10.1063 / 1.124853$

[13] Ell J., Georg A., Arntzen M., Gombert A., Graf $W$., Wittwer V. // Solar Energy Materials and Solar Cells. 2007. V. 91. P. 503-517. doi 10.1016/j.solmat.2006.05.012

[14] Borgschulte A., Gremaud R., de Man S., Westerwaal R.J., Rector J.H., Dam B., Griessen R. // Appl. Surface Sci. 2006. V. 253. P. 1417-1423. doi 10.1016/j.apsusc.2006.02.017

[15] Slack J.L., Locke J.C. // Solar Energy Materials and Solar Cells. 2006. V. 90. P. 485-490. doi 10.1016/j.solmat.2005.02.015

[16] van Gogh A.T.M., van der Molen S.J., Kerssemakers J.W.J., Koeman N.J., Griessen R. // Appl. Phys. Lett. 2000. V. 77. P. 815-817. doi 10.1063/1.1306643

[17] Farangis B., Nachimuthu P., Richardson T.J., Slack J.L., Meyer B.K., Perera R.C.C., Rubin M.D. // Solid State Ionics. 2003. V. 165. P. 309-314. doi 10.1016/j.ssi.2003.08.041

[18] Bao S., Yamada Y., Okada M., Yoshimura K. // Jpn. J. Appl. Phys. 2006. V. 45. L588-L590. doi 10.1143/JJAP.45.L588

[19] Bao S., Tajima K., Yamada Y., Okada M., Yoshimura K. // Solar Energy Materials and Solar Cells. 2008. V. 92. P. 216-223. doi 10.1016/j.solmat.2007.02.023

[20] Bao S., Tajima K., Yamada Y., Okada M., Yoshimura K. // Materials Transactions. 2008. V. 49. P. 1919-1921. doi 10.2320/matertrans.MRP2008117

[21] Bao S., Yamada Y., Tajima K., Okada M., Yoshimura K. // Solar Energy Materials and Solar Cells. 2009. V. 93. P. 1642-1646. doi 10.1016/j.solmat.2009.05.002

[22] Yamada Y., Bao S., Tajima K., Okada M., Yoshimura K. // Appl. Phys.Lett. 2009. V. 94. P. 191910-1-191910-3. doi 10.1063/1.3138130

[23] Yamada Y., Sasaki H., Tajima K., Okada M., Yoshimura K. // Solar Energy Materials and Solar Cells. 2012. V. 99. P. 73-75. doi 10.1016/j.solmat.2011.04.016

[24] Yamada Y., Miura M., Tajima K., Okada M., Yoshimura K. // Solar Energy Materials and Solar Cells. 2013. V. 117. P. 396-399. doi 10.1016/j.solmat.2013.06.050

[25] Yamada Y., Miura M., Tajima K., Okada M., Yoshimura K. // Solar Energy Materials and Solar Cells. 2014. V. 125. P. 133-137. doi 10.1016/j.solmat.2014.02.031

[26] Tajima K., Yamada Y., Yoshimura K. // Solar Energy Materials and Solar Cells. 2014. V. 126. P. 227-236. doi 10.1016/j.solmat.2013.07.016

[27] Yamada Y., Kitamura S., Miura M., Yoshimura K. // Solar Energy Materials and Solar Cells. 2015. V. 141. P. 337-340. doi 10.1016/j.solmat.2015.06.006 
[28] Zhang X.-L., Bao S.-H., Xin Y.-C., Cao X., Jin P. // Frontiers of Materials Science. 2015. V. 9. P. 227-233. doi 10.1007/s11706-015-0300-1

[29] La M., Zhou H., Li N., Xin Y., Sha R., Bao S., Jin P. // Appl. Surface Science. 2017. V. 403. P. 23-28. doi 10.1016/j.apsusc.2017.01.106

[30] Yamada Y., Ohura M., Yoshimura K. // Solar Energy Materials and Solar Cells. 2018. V. 183. P. 48-51. doi 10.1016/j.solmat.2018.04.007

[31] Liu Y., Chen J., Peng L., Han J., Deng N., Ding W., Chen $W$. // Materials and Design. 2018. V. 144. P. 256-262. doi 10.1016/j.matdes.2018.02.023

[32] Liu Y., Chen J., Peng L., Deng N., Ding W. // Intern. J. Hydrogen Energy. 2019. V. 44. P. 15205-15217. doi 10.1016/j.ijhydene.2019.04.099

[33] Yoshimura K., Yamada Y., Bao S., Tajima K., Okada M. // Jpn. J. Appl. Phys. 2007. V. 46. P. 4260-4264. doi 10.1143/JJAP.46.4260

[34] Yoshimura K., Tajima K., Yamada Y., Okada M. // Jpn. J. Appl. Phys. 2010. V. 49. P. 075701-1-075701-4. doi 10.1143/JJAP.49.075701

[35] Yamada Y., Miura M., Tajima K., Okada M., Yoshimura K. // Solar Energy Materials \& Solar Cells. 2014. V. 126. P. 237-240. doi 10.1016/j.solmat.2013.06.041

[36] van der Molen S.J., Nagengast D.G., van Gogh A.T.M., Kalkman J., Kooij E.S., Rector J.H., Griessen R. // Phys. Rev. B. 2001. V. 63. P. 235116-1-235116-8. doi 10.1103/PhysRevB.63.235116

[37] Janner A.-M., van der Sluis P., Mercier V. // Electrochim. Acta. 2001. V. 46. P. 2173-2178. doi 10.1016/S0013-4686(01)00371-1

[38] Yoshimura K., Yamada Y., Bao S., Tajima K., Okada M. // Solar Energy Materials and Solar Cells. 2009. V. 93. P. 2138-2142. doi 10.1016/j.solmat.2009.03.023

[39] Tajima K., Yamada Y., Bao S., Okada M., Yoshimura K. // Surface \& Coatings Technology. 2008. V. 202. P. 5633-5636. doi 10.1016/j.surfcoat.2008.06.098

[40] Development of a Switchable Mirror Sheet Using a New Gasochromic Method. Translation of AIST press release on January 23, 2013. http://www.aist.go.jp/aist_e/latest_research/ 2013/20130304/20130304.html

[41] Yamada Y., Bao S., Tajima K., Okada M., Yoshimura K., Roos A. // Solar Energy Materials and Solar Cells. 2008. V. 92. P. 1617-1620. doi 10.1016/j.solmat.2008.07.011

[42] Tajima K., Yamada Y., Bao S., Okada M., Yoshimura K. // Electrochem. and Solid-State Letters. 2007. V. 10. J52-J54. doi 10.1149/1.2430568

[43] Tajima K., Yamada Y., Bao S., Okada M., Yoshimura K. // Appl. Phys. Lett. 2007. V. 91. P. 051908-1-051908-3. doi $10.1063 / 1.2761842$

[44] Tajima K., Yamada Y., Bao S., Okada M., Yoshimura K. // J. Appl. Phys. 2008. V. 103. P. 013512-1-013512-5. doi 10.1063/1.2829816

[45] Tajima K., Yamada Y., Okada M., Yoshimura K. // Thin Solid Films. 2010. V. 519. P. 934-937. doi 10.1016/j.tsf.2010.09.021

[46] Tajima K., Hotta H., Yamada Y., Okada M., Yoshimura K. // Vacuum. 2013. V. 87. P. 155-159. doi 10.1016/j.vacuum.2012.08.003

[47] Tajima K., Yamada Y., Yoshimura K. All-solid-state Reflective Dimming Electrochromic Element Sealed with Protective Layer and Dimming Member Comprising the Same. Patent US 8773746 B2. 2014. 